\title{
Firms cash management, adjustment cost and its impact on firms' speed of adjustment: a cross country analysis
}

\author{
Qazi Awais Amin ${ }^{1} \cdot$ Tom Williamson ${ }^{1}$ \\ Published online: 8 May 2020 \\ ○ Springer Science+Business Media, LLC, part of Springer Nature 2020
}

\begin{abstract}
We investigate the firms' specific attributes that determine the difference in speed of adjustment (SOA) towards the cash holdings target in the Scandinavian countries: Denmark, Norway and Sweden. We examine whether Scandinavian firms maintain an optimal level of cash holdings and determine if the active cash holdings management is associated with the firms' higher SOA and lower adjustment costs. Our findings substantiate that a higher level of off-target cost induces professional managers to rebalance their cash level towards the optimal balance of cash holdings. Our results reveal that Scandinavian firms accelerate SOA towards cash targets primarily for the precautionary motive. Moreover, our results show that SOA is heterogeneous across Scandinavian firms based on adjustment cost and deviate cash holdings towards the target mainly with the support of internal financing. Furthermore, our empirical findings show that the SOA of Norwegian firms is significantly higher than the Danish and Swedish firms.
\end{abstract}

Keywords Cash holdings $\cdot$ Speed of adjustment $\cdot$ Trade-off theory $\cdot$ Scandinavian countries $\cdot$ GMM

JEL Classification G30 · G32

\section{Introduction}

Managing cash has recently been a vital managerial decision for the optimal utilization of corporation funds (Megginson et al. 2014). The decision to accumulate or deploy cash in excess of cash level for business operations and ongoing contractual obligations are at the discretion of professional managers. The extant literature suggests that the risk of inadequate cash and cost of excess cash should be balancing to regulate the cash levels. Recent empirical evidence shows that firms hold a substantial and increasing part of their assets as cash. The literature widely documents why firms manage excess cash balance, hence,

Qazi Awais Amin

qazi.amin@coventry.ac.uk

Tom Williamson

tom.williamson@coventry.ac.uk

1 Coventry Business School, Coventry University, Gosford Street, Coventry CV1 5ED, UK 
have reported several explanations, however, limited research has evaluated firms' speed of adjustment (SOA) towards the target cash holdings.

The substantial increase in the firms' cash holdings in the US market, the financial downturns of large business groups and the global financial crisis of 2008-2009, all make it important to understand the dynamics of firms' cash management (Bates et al. 2009). In general, firms give preference to cash over debt to finance their short-term investment projects before issuing new equity (Brick and Liao 2017). The determinants of firms' cash holdings have extensively discussed in prior literature particularly in the US context (e.g., Bates et al. 2009; Bates et al. 2018; Dittmar and Duchin 2010; Dittmar and MahrtSmith 2007; Gao et al. 2013; Harford et al. 2008; Nikolov and Whited 2014; Opler et al. 1999) while in the global firms context (e.g., Dittmar et al. 2003; Kalcheva and Lins 2007; Nguyen 2018).

The extant literature has primarily examined two aspects of firms' cash holdings: the level of cash holdings (e.g., Bates et al. 2009; Foley et al. 2007; Lee and Lee 2009; Opler et al. 1999) and the valuation of cash level (e.g., Dittmar and Mahrt-Smith 2007; Faulkender and Wang 2006; Kalcheva and Lins 2007; Orlova et al. 2017; Pinkowitz et al. 2006). However, there is limited empirical research on cash holdings speed of adjustment (see, for example, Dittmar and Duchin 2010; Guariglia and Yang 2018; Orlova and Rao 2018). Importantly, these studies are in the US and Chines context and the empirical findings of these studies are contradictory and inconclusive. For example, Dittmar and Duchin (2010) find a slower adjustment speed across several decades and conclude that on average cash deficit firms are slower than cash surplus firms. On the other hand, Orlova and Rao (2018) used a data set of US firms and examine the sensitivity of cash holdings SOA towards the size and sign of deviation from target cash holdings and report that firms with cash deficit and financial surplus have slow adjustment speed. Moreover, using a panel of 1478 Chinese listed firms Guariglia and Yang (2018) conclude that firms with a greater level of excess cash have higher adjustment speed. Brick and Liao (2017) take into consideration the firms' different level of excess cash holdings and linked it with diverse adjustment cost. It is noticeable that the aforementioned limited empirical research of SOA focuses on the US and Chinese framework and report inconclusive results. Moreover, the governance structure, institutional mechanism and legal framework of China and US differ from the European market. Further, it is important to examine the dynamics of cash holding SOA in the European context for a better understanding of factor affecting firms' SOA. Therefore, limited research of cash holdings SOA creates a research gap to conduct a comprehensive study to understand the dynamics of cash holdings SOA in the Scandinavian framework.

Scandinavian context is an interesting setting to understand the dynamics of cash holdings SOA. The Scandinavian countries belong to the common Scandinavian civil law and characterized by relatively greater investor protection and domination of family and foreign ownership compared to other civil law countries. La Porta et al. (1998) document that Scandinavian countries are deemed to be considered the member of a relatively homogeneous group in term of corporate governance mechanism. The Scandinavian common law suggests a supervisory board which manage the appointment of managers and take the firms key decisions. Moreover, the most significant feature of Scandinavian boards is the appointment of employee representation. The corporate employees are entitled to have one-third representation in board decision making which helps to support the sense of solidarity and minimize management and employees' conflicts. Based on the aforementioned distinct institutional and governance mechanism we conjecture that the cash management approach of the Scandinavian market tends to differ from those in other markets particularly the US and Chines context. 
We contribute to the literature by investigating the firm-specific attributes that determine the difference in firms' speed SOA towards the cash holdings target across Scandinavian countries such as Denmark, Norway and Sweden. To our knowledge no prior study has examined the cash holdings SOA in the Scandinavian countries context. To this end, we employ a panel of 749 non-financial listed firms over the period of 2000-2016. In doing so, at the first stage, we split the sample into high cash firms and low cash firms and investigate their SOA and cash adjustment period in terms of half-life.

We then determine whether country-specific attributes significantly influence the firms' SOA and examine if the firms are heterogeneous in terms of SOA across Denmark, Norway, and Sweden, a thus-far overlooked aspect of SOA in the Scandinavian countries' context. In addition, we investigate whether SOA differs in terms of higher/lower cash levels, leverage financing and investment levels. Moreover, we explore the effectiveness of firms' cash management policies against financial constraints by categorizing firms as financially constrained (FC) and unconstrained (UC) across four different constraints indices.

Finally, we determine the efficacy of Scandinavian firms in managing cash level and its SOA across pre-financial crisis and post-financial crisis and investigate whether there is a regime shift in the Scandinavian firms demand function of cash holding in response to the financial crisis. More specifically, we test the firms' contingency approach of cash management towards the optimal level of cash holdings in response to the exogenous financial shock, relative to the cash management in more routine, steady-state and stable economic conditions.

Plentiful literature has discussed the trade-off theory and financial hierarchy theory to develop cash holdings model (see, for example, Bates et al. (2018), Bigelli and SanchezVidal (2012), Dittmar et al. (2003), Dittmar and Duchin (2010), Gao et al. (2013), Guariglia and Yang (2018), Harford (1999), Jiang and Lie (2016), Lian et al. (2012), Orlova and Rao (2018) and Venkiteshwaran (2011), while the literature pertinent to the firms' SOA is inconclusive and still in the developing stage. We test both theoretical approaches e.g., trade-off and financial hierarchy theories in the Scandinavian countries context and link our empirical model with the precautionary and speculative motives of cash holdings.

Our core findings advocate the view that Scandinavian firms are not persistent across high cash firms and cash deficit firms, hence, adjust their cash balance towards an optimal level of cash holdings for the precautionary motive. Our results reveal an imperfect and continuous deviation of Scandinavians firms cash holdings towards the target with an adjustment speed of (0.428). This SOA is significantly lower than US firms (0.540) document by Orlova and Rao (2018) while its marginally close to the global sample of Dittmar and Duchin (2010) who document SOA ranging between (0.353) and (0.433). Moreover, our results report that Scandinavians firms covering cash adjustment period of half-life ranging between (1.386) and (1.619) years. Our empirical findings show that the SOA of Norwegian firms is significantly higher than the Danish and Swedish firms due to the stable cash holdings level. Our analysis substantiates that financially constrained (FC) firms cover their transaction cost for unconditional liquidity, and relatively sensitive than unconstrained (UC) firms towards the optimal cash level, and quickly deviate their cash towards the target. Moreover, we report that Scandinavian firms prefer to hold more cash during the post-crisis period compared to the pre-crisis period for the transactional and precautionary motives which lead to a faster SOA. The paper is organized as follows. Section 2 provided literature review and hypothesis development. Section 3 describes the data and research strategy, Sect. 4 presents the various model estimations and results analysis, while Sect. 5 concludes the findings. 


\section{Cash holdings theories}

The extant literature has mainly discussed two theories of cash holdings such as tradeoff theory and financial hierarchy theory (Bates et al. 2018; Dittmar et al. 2003; Dittmar and Duchin 2010; Ferreira and Vilela 2004; Gao et al. 2013; Guariglia and Yang 2018, Opler et al. 1999; Ozkan and Ozkan 2004). The trade-off theory explains two motives of firm cash holdings such as transaction motive and the precautionary motive (Jun and Jen 2003). The transaction motive recommends firms to maintain an adequate level of cash holdings as the borrowing from the capital market are comparatively more expensive. The precautionary motive suggests that firms may reduce investments during the period of cash shortage and hold cash for precautionary needs (Kim et al. 1998; Ozkan and Ozkan 2004). In addition, the trade-off theory argues that firms prefer an optimal level of cash reserve by developing a balance between marginal cost and marginal benefits. Trade-off theory predicts that most of the firms prefer to actively deviate cash holdings towards optimal cash levels, however, firms need to be trade-off the adjustment costs against the cost of operating below the optimal level of cash holdings (off-target costs). Therefore, firms' SOA is directly associated with adjustment costs. For example, if the adjustment cost is zero, firms can maintain optimal cash level while in the case of higher adjustment costs (e.g., costs of external borrowing and financial constraints), it's harder for firms to re-adjust their cash balance towards optimal cash target.

The static notion of trade-off theory predicts a quicker adjustment towards cash target, while the dynamic approach of trade-off model takes into consideration other factors such as adjustments costs and market frictions that tend to slow down the SOA towards cash targets. Most of the cash holdings literature plagued with econometric issues such as endogeneity and simultaneity and develop their hypothesis based on static models (see, for example, Kim et al. 1998; Martinez-Sola et al. 2018; Opler et al. 1999). The static trade-off model is unable to fully account for adjustment cost and off-target cost, while the dynamic trade-off model provides more consistent estimation by considering all relevant adjustment cost for optimal cash level. Therefore, the present study employed both estimation version e.g. dynamic and static techniques for model estimation to determine SOA across sample firms.

A large strand of studies documents that firms hold cash more than their operational and investment requirements (see, for example, Ditmar and Smith 2007; Bates et al. 2009). Moreover, Bates et al. (2009) report that the cash ratio of US firms become more than double from 1980 to 2006. The possible reasons for large firms' cash holdings are the transactional motive, precautionary motive, research \& development and investment opportunities. The agency theory predicts that there is a conflict between shareholders and managers and there is a possibility that managers hold more cash to peruse their personal interest (Harford et al. 2008).

The firms hold more cash for the transaction and precautionary motives to protect themselves when they expect future cash flow uncertainty or high costs of external financing (Han and Qiu 2007). Agency theory predicts that the countries where shareholder protection are not strong, firms prefer to hold more cash (Pinkowitz et al. 2006). Moreover, when agency problems are severe then the value of cash holdings is worth-less. The self-centred managers are more likely to hoard cash, rather making dividend payments. Moreover, Jensen (1986), argues that firms with agency problems tend to hoard cash when there is a lack of investment opportunities and the self-centred managers do not want to return cash to shareholders. 
On the other hand, the financial hierarchy theory is not suggesting an optimal level of cash and focus on the balance between investment needs and retained earnings (Myers and Majluf 1984). The financial hierarchy theory portrays a hierarchy of source of funds by suggesting that finance can be generated from retained earnings, internal debt and equity. In addition, financial hierarchy theory posits that the level of cash holdings depends upon capital needs for investment opportunities without having an optimal level of cash holdings. Therefore, shareholders are ready to accept a high level of cash holdings to get benefit from potential investments opportunities if their interest is protected by effective corporate governance. Moreover, financial hierarchy theory argues that the firms prefer to hold cash when external resources are expensive and go beyond the firms' affordability compared to internal resources. Opler et al. (1999) document that financial hierarchy theory considers asymmetric information as a primary issue of effective decision making because the external funds become costly for the firms due to asymmetric information, consequently firms prefer to utilize retained earnings to avoid external financing. Furthermore, the prior studies such as Kim et al. (1998) and Opler et al. (1999) rely on single period trade-off to determine the cash level between the costs and benefits of firms' liquid assets. In contrast to the prior studies, we estimate both the theoretical models i.e. trade-off and financially hierarchy model to determine the relevance of the Scandinavian countries' context.

Several prior studies in the UK and USA context substantiated that firms cash holdings policies are influenced by the trade-off model (see, for example, Kim et al. 1998; Han and Qiu 2007; Opler et al. 1999; Ozkan and Ozkan 2004; Venkiteshwaran 2011). Therefore, based on prior the studies' findings we expect that Scandinavian firms' cash holdings are better explained by trade-off theory. Therefore, following the theoretical framework of Opler et al. (1999), we developed our first hypothesis:

Hypothesis $\mathbf{H}_{\mathbf{1}}$ Cash holdings strategies of Scandinavian firms are better defined by the trade-off model compared to the financial hierarchy model.

\section{Literature review}

The optimal level of cash holdings is less likely to be focused in the perfect capital market as the firms have easy access to external funds and invest in potential investment opportunities, particularly when the firms' internal funds are not enough for investment. In addition, firms tend to optimize and adjust their level of cash reserve in response to the macrolevel changes in the economy. Moreover, inflation and interest rate are the common factors which directly associated with the purchasing power of the firms and directly impact on their cash holdings.

The optimal cash holdings level is irrelevant in the perfect capital market as firms have easy access to external funds to invest in potential investment opportunities whenever internal funds are insufficient for investment. Moreover, firms have indifferent behaviour in relation to internal and external financing. (Myers and Majluf 1984). Furthermore, firms subject to greater imperfections tend to hold more cash as it enhances firms' ability to initiate profitable investment when they face a shortage of internal funds and external finance is too costly. However, it is recognised that a higher level of cash holding associate with costs.

Two versions are reported in the literature to manage the unobserved cash holdings target. First, Opler et al. (1999) suggest that cash holdings target can measure by taking the 
mean or the moving average of the observed cash ratio. This approach based on the weak assumption that target cash level depends on firms' past cash holdings level and remain consistent over time. The second version states that cash holdings target is deemed to be a specific ratio derived from firms' characteristics (Garcia-Teruel and Martinez-Solano 2008. The present study examines both the version in the Scandinavian context.

A large strand of studies document that firms higher level of cash holding is useful in mitigating cash shortfall and enhance firm access to profitable investment opportunities (e.g., Almeida et al. 2004; Chen et al. 2012; Harford et al. 2008; Opler et al. 1999; Riddick and Whited 2009). Kim et al. (1998) reveal that firms prefer to hold a higher level of cash holdings to maintain financial flexibility to manage unexpected market shock. Venkiteshwaran (2011) examines a sample of US manufacturing firms and report that adjustment of excess cash firms is slower than low cash firms while at faster deviation of small size firms than large size firms.

The concurrent studies such as Fischer et al. (1989) and Oztekin and Flannery (2012) point out that firms rebalance their target level of leverage when adjustment cost is lower than the non-adjustment cost (off-target cost). In a similar vein, this argument can be examined in the context of the target level of cash holdings as the primary source of adjustment cost is the transaction costs associated with the distribution of cash to shareholders and the cost of raising capital to maintain the cash holdings target. Accordingly, we take into consideration the adjustment cost and off-target cost of firms' optimal cash level to investigate whether Scandinavian firms rebalance their cash holding towards optimal cash level.

The cash holdings deviation towards the target level is directly associated with the firms' adjustment costs which depend on firms' specific characteristics and the level of financial market imperfection. Therefore, firms' SOA link with adjustment costs and its individual attributes in relation to firm capacity to manage cash holdings level. Therefore, a higher adjustment cost affects the firms' efficiency to adjust cash levels and, consequently slow down the SOA. On the other hand, firms suffer off-target costs when professional managers unable to maintain an optimal level of cash holdings. A higher level of off-target cost induces firms to review their cash policy to adjust their cash balance towards the optimal level of cash holdings. We, therefore, argue that cash level and adjustment costs play a significant role in determining the Scandinavian firms' cash holdings SOA. Hence, we hypothesize:

Hypothesis $\mathbf{H}_{\mathbf{2}}$ The difference in financial constraints levels and adjustment costs lead to different levels of cash holdings SOA.

Almeida et al. (2004) document that when the firms have enough financial worth to acquire the first available profitable investment opportunity during the financial crisis and in stable economic conditions are considered as unconstrained (UC) firms. In contrast, financially constrained (FC) firms are relatively small, young and face more financial friction when borrowing finance from the capital market. We, therefore, take into consideration the determinants of cash holdings and postulate that FC firms prefer internal finance due to the limited access to external financial resources and tend to hold a higher level of cash holdings. Furthermore, FC firms are more focused to meet their precautionary motive and less concerned about potential investment opportunities (Opler et al. 1999). Moreover, UC firms have more financial worth than FC firms which allow them to acquire the first available profitable investment opportunity (Almeida et al. 2004). The prior stream 
of literature classify firms as FC and UC based on different constraints criteria such as the firms capacity to access capital markets, bond rating, firm size, dividend payment, payout ratio, leverage, WW index, collateral assets and life cycle (see, for example, Almeida et al. 2004; Chang et al. 2017; Chan et al. 2012; Denis and Sibilkov 2010; Lee and Park 2016; Martinez-Sola et al. 2018).

We investigate the impacts of financial constraints on firms' cash holdings and their SOA by categorizing firms as financially constrained (FC) and unconstrained (UC) firms based on four different constraint indices and tests the effectiveness of firms' cash management policies against financial constraints. ${ }^{1}$ These constraints criteria are dividend payment, firm size, firms' growth and interest coverage ratio which helps to measure the firms' financial constraints. Moreover, the firms' precautionary and speculative motives are directly associated with financial constraints. Han and Qiu (2007) document that financially constrained (FC) firms prefer to hold more cash for precautionary motive particularly in the situation of volatile cash flows to minimise financing cost and to avoid bankruptcy. In the case of speculative motive, firms prefer to hold larger cash to compete for their industrial rivals by acquiring potential investment opportunities. We, therefore, argue that the consideration of precautionary and speculative motives makes the professional managers of FC firms more sensitive towards cash shortage. In addition, we conjecture that financial constraints significantly influence firms' cash holdings policies which affect SOA, therefore, we expect that the firms' SOA is highly sensitive to financial constraints. Hence, we hypothesize:

Hypothesis $\mathbf{H}_{3}$ SOA of financially constrained (FC) firms is more sensitive to optimal cash levels than unconstrained (UC) firms.

The firms maintain an adequate level of cash holdings to secure against unexpected market slump and credit shocks to avoid expensive external borrowing. Venkiteshwaran (2011) documents that imperfect capital market impact negatively on the maintaining of the optimal level of cash holdings. Baum et al. (2006) point out that macroeconomic factors of financial crisis tend to influence the firms' cash holdings targets. Moreover, the financial crisis negatively impacts on firms' profitability, cash flows which in turn reduce the expected return on investment (Arslan-Ayaydin et al. 2014; Kwak et al. 2012). In addition, the financial crisis affects the capital markets functioning which limit the firms' access to external borrowing, therefore, firms tend to face the shortage of cash flow problems. Further, we argue that the countries where corporate governance mechanism is not followed in the true sense, firms are not a risk-taker. Therefore, during financial crisis firms have relatively less access to profitable investment opportunities and face more financial distress and as a result, prefer to hold more cash. Ferreira and Vilela (2004) reveal that during the financial crisis, firms prefer to increase their level of cash holdings to reduce their default risk. Santos (2011) report that the banks reduce their credit in response to the

\footnotetext{
1 We categorise firms as financially constrained (FC) and unconstrained (UC) if they are below (above) of industry median in term of total assets for firm size criteria, and take 1 if firms pay the dividend, and 0 otherwise. For growth and interest coverage ratio criteria, sample firms are classified as FC and UC if firms are above (below) of industry median of sample firms. Based on these classifications, the non-dividend paying firms, small size firms, low growth firms, and low-interest coverage ratio firms are categorised as FC firms otherwise, UC firms. For growth criteria, firms' growth defines as an increase in the firm's annual sale compares to the preceding year. Previous studies such as Han and Qiu (2007) use 'Bond rating' and 'CP rating' while Almeida et al. (2004) use paper rating to classify firms as financially constrained and unconstrained firms. We ignore these criteria because of data limitations.
} 
financial crisis which increases the firms' cost of external financing while Belghitar and Khan (2013) argue that increased cash holding is helpful in minimizing the intensity of the financial crisis.

Kahle and Stulz (2013) argue that firms which depending on external financing during stable economic conditions are more likely be affected during crisis whilst the firms which do not rely on credit market would be less affected during the crisis period. Dittmar and Duchin (2010) report that financially constrained firms are more affected by the financial crisis as they reduce the investment projects and increase their level of cash holdings in response to high risk and asymmetric information.

The extant literature develops a model of cash holdings by considering transactional motives and discuss the variation in cross-sectional firms' cash holdings mainly for US firms (Song and Lee 2012). The firms prefer to hold less cash holdings when the opportunity cost of money is higher and willing to hold more cash when they have a higher transaction cost to convert non-cash assets into cash. In the pre-crisis period, the firms enjoy an abundance of profitable investment opportunities due to higher financial stability and large volume of business. In contrast, during the financial crisis period firms have limited investments opportunities due to the lower rate of return and the depression in economy. Therefore, the same hypothesis may not be generalized for both samples i.e. pre-crisis and during crisis period.

The present study classifies the sample observations across the pre-crisis and post-crisis period as the access to external finance is likely to be limited during the post-crisis period due to the market imperfection. Moreover, when the financial crisis hit firms' cash holdings below or above the optimal level, one would expect a quicker SOA to rebalance the cash holdings towards the target. In doing so, we take into consideration the firms' characteristics that capture the difference in observed SOA across the pre-crisis and post-crisis period. Based on the above discussion we develop our fourth hypothesis:

Hypothesis $\mathbf{H}_{4}$ Firms SOA towards an optimal level of cash holdings during the postcrisis period is quicker than the pre-crisis period.

\section{Research strategy}

\subsection{Data and sample}

We use a sample of 749 non-financial listed firms of Scandinavian countries such as Denmark, Norway and Sweden over the period 2000-2016 to conduct our empirical analysis. The sample develops mainly from the Thomson Reuters Worldscope database. In addition, Financial industries (SIC codes, 6000-6999) and Utilities (SIC codes, 4900-4999) are excluded subject to differences in the applicable regulatory requirements of the individual countries. Firms with missing data during the sample period are excluded from the sample while observations are dropped if the value of firms' cash holdings and total assets is missing. This results in an unbalanced panel data set of 11,842 firm-years observations. Furthermore, the variables are winsorized at the $1 \%$ level.

Panel A of Table 1 shows summary statistics for the variable used in this study. The cash holding is the ratio of cash and cash equivalents to total assets. The mean (median) of cash holdings is $12.7 \%$ (9.6\%) which is less than the cash holdings of US firms of $16.5 \%$ in 2000 to $20 \%$ in 2012. In addition, these cash holdings ratios of Scandinavian firms are 


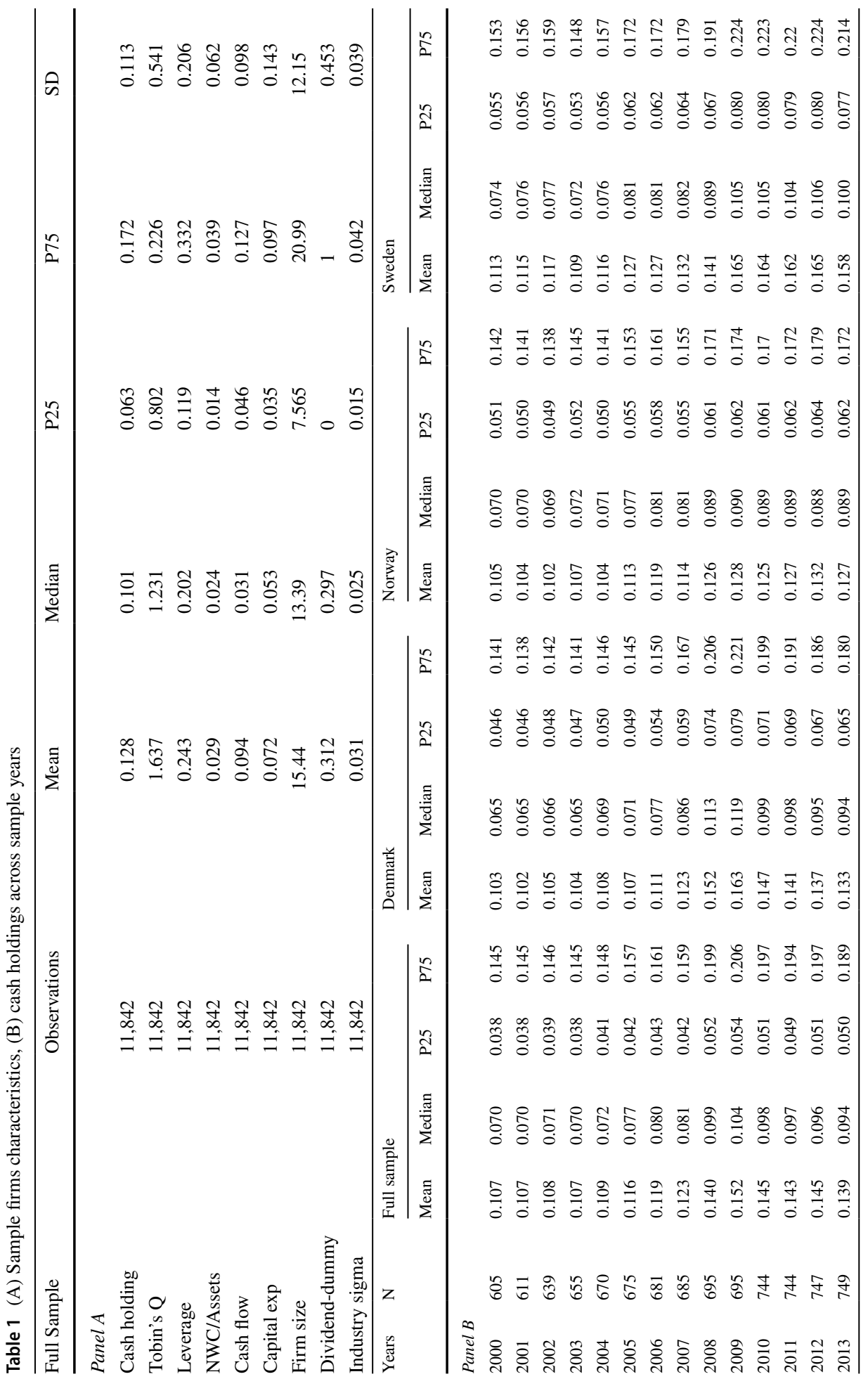




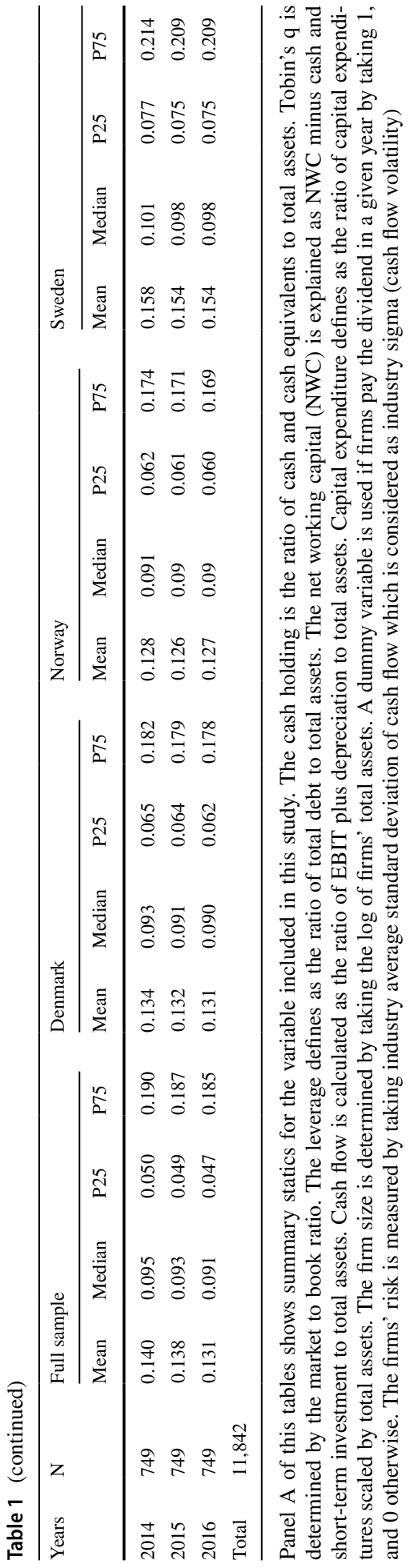


slightly greater than UK firms (10\%), reported by Ozkan and Ozkan (2004) while less than Chines firms (14.7\%) and US firms (16\%) document by Guariglia and Yang (2018) and Opler et al. (1999), respectively. Moreover, Tobin's Q is determined by the market to book ratio and the mean (median) of Tobin's $\mathrm{Q}$ is 1.637 (1.231). The leverage defines as the ratio of total debt to total assets with the mean (median) value of $24.3 \%$ (20.2\%). The net working capital (NWC) is explained as NWC minus cash and short-term investment to total assets. The mean (median) of NWC ratio is $2.9 \%$ (2.4\%). The cash flow is $9.4 \%(5.1 \%)$ which is calculated as the ratio of EBIT plus depreciation to total assets. Capital expenditure defines as the ratio of capital expenditures scaled by total assets. The mean and median of capital expenditure is $5.6 \%(4.9 \%)$. The firm size is $15.44 \%$ (13.39\%) which is determined by taking the log of firms' total assets. A dummy variable is used if firms pay the dividend in a given year by taking 1 and 0 otherwise. The firms' risk is measured by taking industry average standard deviation of cash flow which is considered as industry sigma (cash flow volatility). The mean (median) of industry sigma is $4.7 \%$ (3.9\%).

Panel B of Table 1 presents the time series analysis of cash holdings mean (median) ratio on a yearly basis to investigate the cash holdings trends in Scandinavian firms. The mean of cash holdings is marginally increased during pre-crisis period i.e. (2000-2007) from 10 to $11 \%$ and then there is a dramatic increase in the mean (median) of cash holdings from $11.7 \%$ (8.9\%) in 2007 to $14.7 \%$ (11.1\%) in 2008. In addition, the cash holdings ratio of the individual samples such as Denmark, Norway and Sweden are 11.23\%, 11.44\% and $12.65 \%$ respectively in the pre-crisis period and significantly increase during the post-crisis period up to $15.63 \%, 12.28 \%$ and $16.24 \%$, respectively. It is noticeable that the cash holding of Norway remains consistent and insignificantly increased in the post-crisis compared to Denmark and Sweden.

\section{Results and discussion}

We conjecture that sample firms exhibit the mean-reverting characteristics, as it's established by the prior studies such as Dittmar and Duchin (2010), Opler et al. (1999). We, therefore, develop the following equation:

$$
\Delta\left(\text { Cash/Asset }_{\text {,it }}\right)=\alpha+\beta \Delta\left(\text { Cash/Asset }_{\mathrm{it}-1}\right)+\varepsilon_{\mathrm{it}}
$$

where $\Delta\left(\mathrm{Cash}_{\text {/Asset }}{ }_{\mathrm{it}}\right)$ determines the first difference (adjustments in cash) from one period to the next while $\beta \Delta$ (Cash/Asset $\left.{ }_{i t-1}\right)$ represent the lagged level of cash holdings.

\subsection{Mean reversion of firms' cash levels}

We begin our analysis by investigating firms' tendency to revert cash holdings level towards the target. Therefore, we categories firms into deciles of cash holdings to examine whether firms' cash holdings level revert in the subsequent year and present the findings in Fig. 1. The horizontal axis of Fig. 1 shows firms with lowest cash levels or cash deficit display ( $3.4 \%$ decile) to the highest level of cash balances of $(28.3 \%$ decile). The vertical axis shows the change in mean and median of cash holdings. The results demonstrate that firms adjust their cash level in the subsequent year. In addition, the firms with excess cash tend to reduce their cash holdings level while cash deficit firms increase their cash balance, however, excess cash firms increase their cash level more by $(4.81 \%)$ than the decrease in 


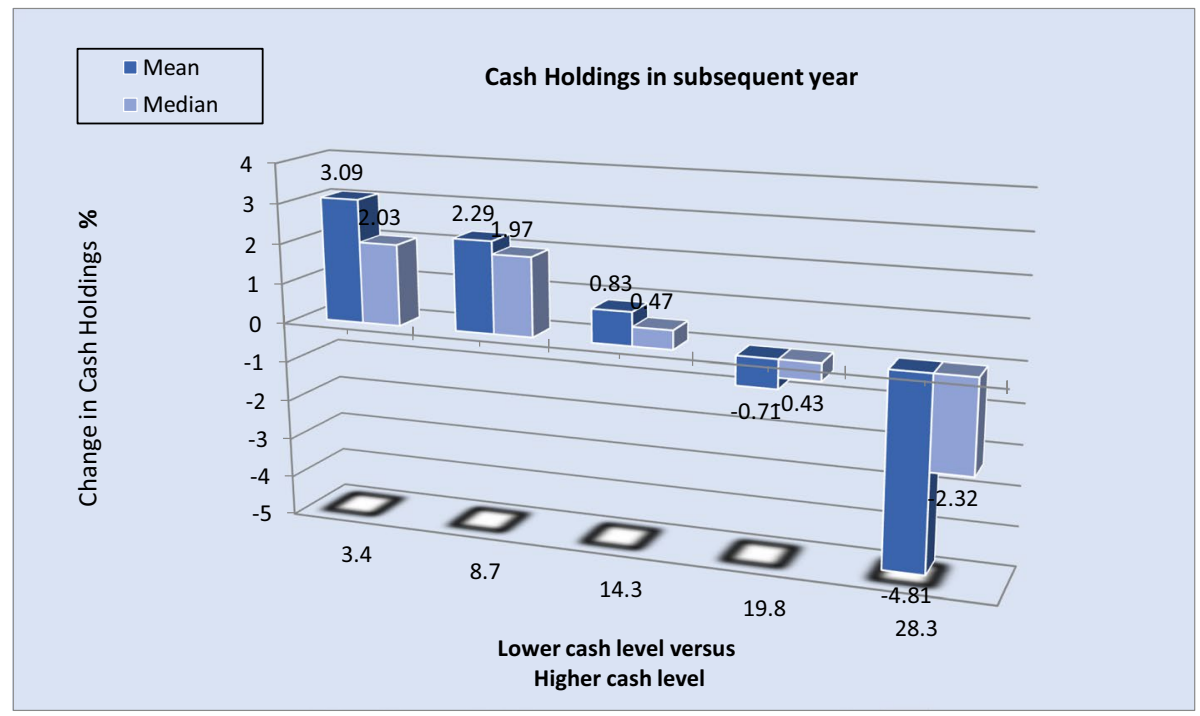

Fig. 1 Cash holdings in subsequent year

cash level of (3.09\%) by cash deficit firms. These statistics demonstrate that cash holdings of Scandinavian firms are not persistent across excess cash firms and cash deficit firms as they adjust their cash level in the subsequent year.

\subsection{High cash firms and cash deficit firms' adjustment towards the target cash holdings}

We further investigate whether high cash firms have excess cash than their target levels and cash deficit firms have a lower level of cash towards their target level and present the results in Fig. 2. As Fig. 1, the horizontal axis presents firms' deciles allocation from the lowest to the highest cash level while the vertical axis determines the firms' cash deviation from their estimated target levels. In addition, Fig. 2 shows that excess cash firms exceed the target by $23.15 \%$, whereas low cash and cash deficit firms fall short from their targets by $9.92 \%$. This evidence shows that on average Scandinavian firms' cash level is positively correlated with the level of deviation from expected optimal cash level.

\subsection{Firms cash rebalancing behaviour: a two-stage model}

We extend our analysis by estimating a two-stage model for controlling firms and industry characteristics to determine the firms' cash rebalancing behaviour by following Opler et al. (1999). We estimate the firms target level of cash balance and then regress levels of actual cash holdings on the firms' deviation to examine that to what extent firms adjust their cash holdings level towards an estimated target and present the results in Table 2.

Opler et al. (1999) have used moving average of past cash holding levels and estimate the optimal level of cash holdings while using firms and industry level attributes Bates et al. (2009) determine the firms' cash level and obtain fitted values from the association 


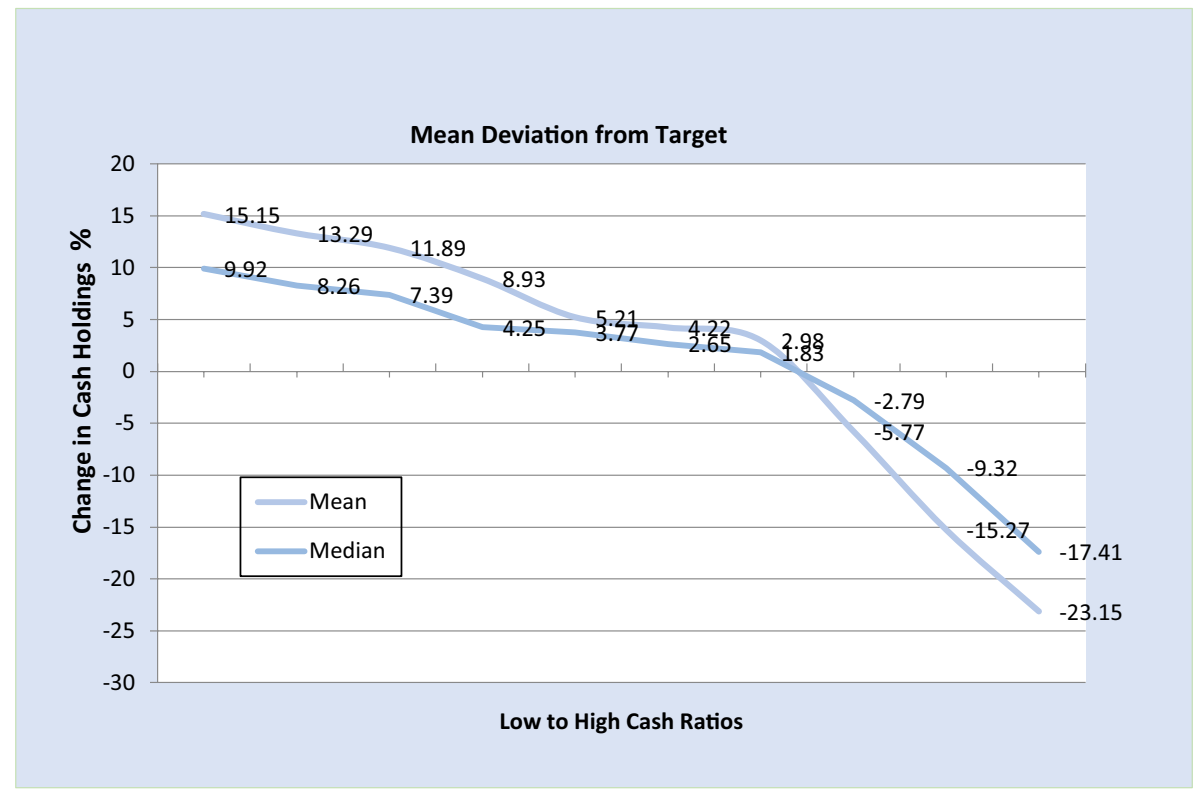

Fig. 2 Cash deviation from optimal cash level

between firms' actual cash holding and the industry level attributes. Therefore, following Bates et al. (2009) and Opler et al. (1999), we examine the common factors that expected to influence the firms' level cash holdings and develop the following model.

Cash/Assets = f (Tobin's Q, Leverage, NWC, Cash flow,

Capital exp, Firm size, Dividends, Industry sigma).

In addition, we investigate the magnitude of the deviations that firms adjust in 1-year period i.e. expected adjustment rate by the following equation.

$$
\Delta \text { Cash/Assets }=\alpha+\beta\left(\text { Cash/Assets }{ }^{*}-\text { Cash/Assets }\right)_{\mathrm{it}-1}+\varepsilon_{\mathrm{it}}
$$

where $\Delta$ Cash/Assets is the observed change or adjustment in the level of cash holdings while the right-hand side of Eq. (3) establish the deviation from actual to target level of cash holdings. Moreover, $\alpha$ and $\beta$ denote the estimated coefficients and $\beta$ capture the range of deviation from the target level of cash holdings. We estimate the fitted values i.e. (Cash/ Assets ${ }^{*}$ ) from Eq. (2) and simultaneously determine each firm-years deviation from actual cash holdings to estimated target levels (e.g., Cash/Assets* - Cash/Assets).

Table 2 presents the cash holding regression results. Model 1 shows pooled OLS estimation while model 2 extend Pooled OLS by adding year and industry dummy to control fixed effects. Most of the estimation results of model 1 and 2 are relatively similar in term of coefficient and level of significance. In column 3 we estimate fixed effects model by adding year and industry dummy. The coefficient on Tobin's Q, leverage, NWC, Cash flow, Capital expenditure, dividend and industry sigma are statistically significant while firm size is insignificant. Model 4 estimates Eq. (3) which demonstrates that the estimated adjustment coefficient is statistically significant (0.374), indicating that on average firms 
Table 2 Testing mean reversion of cash holdings

\begin{tabular}{|c|c|c|c|c|}
\hline \multirow[t]{2}{*}{ Variables } & \multicolumn{2}{|l|}{ Panel A } & \multicolumn{2}{|l|}{ Panel B } \\
\hline & $\begin{array}{l}\text { Cash/Assets } \\
\text { (1) }\end{array}$ & $\begin{array}{l}\text { Cash/Assets } \\
\text { (2) }\end{array}$ & $\begin{array}{l}\text { Cash/Assets } \\
\text { (3) }\end{array}$ & $\begin{array}{l}\left(\mathrm{Cash} / \mathrm{TA}^{*}-\mathrm{Cash} / \mathrm{TA}\right) \\
\text { (4) }\end{array}$ \\
\hline Cash holdings & $\begin{array}{l}0.131 * * * \\
(0.314)\end{array}$ & $\begin{array}{l}0.462 * * * \\
(0.542)\end{array}$ & $\begin{array}{l}0.225 * \\
(0.314)\end{array}$ & $\begin{array}{l}0.374 * * * \\
(0.117)\end{array}$ \\
\hline Tobin's Q & $\begin{array}{l}0.451 * * * \\
(0.314)\end{array}$ & $\begin{array}{l}0.432 * * \\
(0.542)\end{array}$ & $\begin{array}{l}0.763 * \\
(0.314)\end{array}$ & $\begin{array}{l}0.372 * * \\
(0.117)\end{array}$ \\
\hline Leverage & $\begin{array}{l}-0.521^{*} \\
(0.171)\end{array}$ & $\begin{array}{l}-0.221^{* *} \\
(0.161)\end{array}$ & $\begin{array}{l}-0.054^{*} \\
(0.221)\end{array}$ & $\begin{array}{l}-0.287 * \\
(0.051)\end{array}$ \\
\hline NWC/Assets & $\begin{array}{l}-0.046^{*} \\
(0.198)\end{array}$ & $\begin{array}{l}-0.421^{*} \\
(0.282)\end{array}$ & $\begin{array}{l}-0.553^{* *} \\
(0.421)\end{array}$ & $\begin{array}{l}-0.014^{* *} \\
(0.211)\end{array}$ \\
\hline Cash flow & $\begin{array}{l}0.152 * * \\
(0.412)\end{array}$ & $\begin{array}{l}0.219 * * \\
(0.381)\end{array}$ & $\begin{array}{l}0.341 * \\
(0.015)\end{array}$ & $\begin{array}{l}0.278 * * \\
(2.354)\end{array}$ \\
\hline Capital exp & $\begin{array}{l}-0.241^{* *} \\
(0.162)\end{array}$ & $\begin{array}{l}-0.198^{* *} \\
(0.152)\end{array}$ & $\begin{array}{l}-0.282^{*} \\
(0.219)\end{array}$ & $\begin{array}{l}-0.224^{* *} \\
(0.653)\end{array}$ \\
\hline Firm size & $\begin{array}{l}0.493 \\
(0.372)\end{array}$ & $\begin{array}{l}0.412 \\
(0.318)\end{array}$ & $\begin{array}{l}0.381 * \\
(0.271)\end{array}$ & $\begin{array}{l}0.015 \\
(0.114)\end{array}$ \\
\hline Dividend-dum & $\begin{array}{l}0.217 * \\
(0.873)\end{array}$ & $\begin{array}{l}0.046^{*} \\
(0.221)\end{array}$ & $\begin{array}{l}0.421 \\
(0.341)\end{array}$ & $\begin{array}{l}0.551 * * \\
(0.613)\end{array}$ \\
\hline Industry sigma & $\begin{array}{l}0.532 * * * \\
(0.291)\end{array}$ & $\begin{array}{l}0.217 * * * \\
(0.162)\end{array}$ & $\begin{array}{l}0.435 * \\
(0.204)\end{array}$ & $\begin{array}{l}0.982 * * \\
(0.941)\end{array}$ \\
\hline Constant & $\begin{array}{l}0.382 * \\
(0.312)\end{array}$ & $\begin{array}{l}0.411 * * * \\
(0.291)\end{array}$ & $\begin{array}{l}0.241 * * \\
(0.162)\end{array}$ & $\begin{array}{l}0.608 * \\
(0.204)\end{array}$ \\
\hline Fixed effects & No & Yes & Yes & Yes \\
\hline Years dummy & No & Yes & Yes & Yes \\
\hline Industry dummy & No & No & Yes & Yes \\
\hline R-squared & 0.27 & 0.42 & 0.33 & 0.49 \\
\hline Adjusted R-squared & 0.21 & 0.37 & 0.29 & 0.38 \\
\hline $\mathrm{N}$ & 11,842 & 11,842 & 11,842 & 11,842 \\
\hline
\end{tabular}

This Table present the results from the estimation of fixed effects which calculated using standard errors robust to serial correlation within panels based on Eqs. (2) and (3). The dependent variable in all regressions is the level of cash holdings (ratio of cash and cash equivalents to total assets). Tobin's q is determined by the market to book ratio. The leverage defines as the ratio of total debt to total assets. The net working capital (NWC) is explained as NWC minus cash and short-term investment to total assets. Cash flow is calculated as the ratio of EBIT plus depreciation to total assets. Capital expenditure defines as the ratio of capital expenditures scaled by total assets. The firm size is determined by taking the log of firms' total assets. A dummy variable is used if firms pay the dividend in a given year by taking 1 and 0 otherwise. The firms' risk is measured by taking industry average standard deviation of cash flow which is considered as industry sigma (cash flow volatility)

$* * *, * *, *$ Represent significance at the $1 \%, 5 \%$, and $10 \%$ level, respectively

covers less than half the gap between their actual cash level and the target level of cash holdings. Furthermore, these results substantiate that firms revert towards optimal cash level in less than 2 years. 


\subsection{Estimation cash holdings theories}

The previous lines analysis is based on the trade-off model which consider the cost and benefits of cash holdings to determine the optimal level of cash holdings and associate with the firms' mean-reverting behaviour. An alternative version is defined by financial hierarchy theory which argues that cash levels are associated with firms' profitability and overall financial position and anticipate a balance between investment needs and internally generated finance (Myers and Majluf 1984). Moreover, the financial hierarchy theory does not suggest an optimal level of cash holding and predict that firms cash levels are linked with the change in firms' internal resources, and firms tend to raise capital when there is lack of funds for potential investment opportunities.

In this section, we conduct a comparative analysis of both theoretical approaches i.e. trade-off and financial hierarchy to determine which theoretical model better define the Scandinavian perspective of cash holdings. Therefore, in the case of financial hierarchy approach firms' cash level tend to directly link with the availability of firms' internal funds, and as a result, the assumption of firms' cash deviation for an optimal level i.e. trade-off theory version would not be significant for the future changes in firms' cash level. To test these distinctive approaches of trade-off and financial hierarchy theories, we following Frank and Goyal (2003) and Opler et al. (1999) and construct a variable 'Financial deficit'. Accordingly, if the behaviour of sample firms is dominating by financial hierarchy theory the variable 'financial deficit' tends to define the significant part of the variation in cash holdings compared to firms' deviation from cash holdings target. We, therefore, define 'Financial deficit' as (dividend payment of ordinary and preference shareholders + short term investment + change in working capital-net cash flow/total assets). Furthermore, to determine whether 'financial deficit' can capture the change in firms' cash holdings, we estimate the following model.

$$
\operatorname{Cash}_{\mathrm{it}+1}-\mathrm{Cash}_{\mathrm{it}}=\alpha+\lambda\left(\mathrm{Cash}_{\mathrm{it}}^{*}-\mathrm{Cash}_{\mathrm{it}}\right)+\beta \text { Financial deficit }_{\mathrm{it}}+v i+\varepsilon_{\mathrm{it}}
$$

where 'cash' represent the firms' cash holdings while cash* denotes the estimated cash holdings target, ' $\lambda$ ' is the firms' SOA, 'financial deficit' represent the firms' financial deficiency across the sample period and $v_{i}$ represent firm-specific effects.

Table 3 present the partial adjustment model of fixed effects based on Eq. (4) while the standard error is used in addition to the year and industry dummy. The change in cash holdings during the subsequent year is treated as a dependent variable in each model. Column 1 present the regression results including 'financial deficit' which shows a significant positive coefficient (0.028) while the value of R-squared (0.05) is relatively small indicating a lower explanatory power of financial deficit variable. Column 2 presents the result of cash holdings deviations from target levels by estimating Eq. (2) which are smiler to the results reported in Table 2. It is noticeable that the value of $\mathrm{R}$-squared is significantly higher than the ones shows in column 1. In column 3, we estimate both measures e.g. cash deviation and the financial deficit variable. The coefficient on both variables i.e. 'cash deviation' and 'financial deficit' is significantly positive indicating that both the variables describe different attributes of firms' cash holdings. In column 4, following Frank and Goyal (2003), we estimate an interaction term between the 'financial deficit' and a dummy variable that equals to 1 if the cash deviations from the target show excess cash level. Column 4 demonstrates that the coefficient on the 
Table 3 Testing cash holdings theories

\begin{tabular}{lllll}
\hline Panel A & $(1)$ & $(2)$ & $(3)$ & $(4)$ \\
\hline (Cash/TA ${ }^{*}$-Cash/TA) & & $0.374^{* * *}$ & $0.036^{* *}$ & $0.053^{* * *}$ \\
Financial deficit (dummy) & $0.028^{* *}$ & $(0.117)$ & $(0.094)$ & $(0.231)$ \\
& $(6.134)$ & & $0.087 * * *$ & $0.046^{*}$ \\
Financial deficit (excess level) & & & $(2.491)$ & $(5.532)$ \\
& & & 0.237 \\
Constant & $0.142^{* * *}$ & $0.608^{*}$ & $0.131^{*}$ & $(0.104)$ \\
R-squared & $(0.114)$ & $(0.204)$ & $(0.061)$ & $0.357^{* * *}$ \\
Adjusted R-squared & 0.05 & 0.49 & 0.32 & $(0.192)$ \\
$\mathrm{N}$ & 0.02 & 0.38 & 0.23 & 0.27 \\
\hline Panel B & 11,842 & 11,842 & 11,842 & 0.21 \\
\end{tabular}

Panel B

Industry level target adjustment $0.622 * * *$

Pooled OLS target adjustment

Fama-MacBeth target adjustment

Fixed effect target adjustment

Dynamic target adjustment

Financial deficit-dummy

\begin{tabular}{lllllll} 
R-squared & 0.61 & 0.37 & 0.44 & 0.29 & 0.48 & 0.04 \\
Adjusted R-squared & 0.49 & 0.31 & 0.37 & 0.23 & 0.41 & 0.01 \\
$\mathrm{~N}$ & 11,842 & 11,842 & 11,842 & 11,842 & 11,842 & 11,842 \\
\hline
\end{tabular}

Panel A of this table presents the partial adjustment model of fixed effects based on Eq. (4), while the standard error is used in addition to year and industry dummy. Column 1 of Panel A presents the regression results, including 'financial deficit', while column 2 presents the result of cash holdings deviations from target levels by estimating Eq. (2), smiler to results reported in Table 2. In column 3, we estimate both measures e.g. cash deviation and the financial deficit variable. Column 4 demonstrates that the coefficient of interaction variable is insignificant indicating that cash holdings of Danish, Norwegian and Swedish firms are more influenced by the trade-off model compared to financial hierarchy theory. Panel B of this table presents the partial adjustment model of fixed effects estimation as a robustness test of Panel A findings which demonstrates that cash holdings of sample firms are explained by the trade-off model and less influenced by the financial hierarchy theory. In column 1-5, Eq. (4) is estimated with the exclusion of 'financial deficit' variable. The industry level estimated target cash (cash $\left.{ }^{*}\right)$ on a yearly basis is presented in column 1 by taking the median of industry cash holdings. Column 2 reports pooled OLS target adjustment, while column 3 includes the fitted values by following Opler et al. (1999). The Fama-MacBeth and fixed effects models are estimated in column 3 and 4 respectively, while column 5 presents the dynamic estimation of Opler et al. (1999) model by taking fitted values of fixed effects estimator. Finally, in column 6, we examine that to what extent 'financial deficit' capture the deviation of cash holdings level

$* * *, * *, *$ Represent significance at the $1 \%, 5 \%$, and $10 \%$ level, respectively 
interaction variable is insignificant indicating that cash holdings of Danish, Norwegian and Swedish firms are more influenced by the trade-off model compared to financial hierarchy theory.

Panel B of Table 3 presents the partial adjustment model of fixed effects estimation as a robustness test of Panel A' findings which demonstrates that cash holdings of sample firms are better explained by the trade-off model and less influenced by the financial hierarchy theory. We estimate Eq. (4) in column 1-5 with the exclusion of 'financial deficit' variable. The industry level estimated target cash (cash ${ }^{*}$ ) on a yearly basis shows in column 1 by taking the median of industry cash holdings. Column 2 reports pooled OLS target adjustment including the fitted values by following Opler et al. (1999).

Fama-MacBeth and fixed effects models are estimated in column 3 and 4 respectively while column 5 presents the dynamic estimation of Opler et al. (1999) model by taking fitted values of fixed effects estimator. Finally, in column 6, we examine that to what extent 'financial deficit' capture the deviation of cash holdings level. The results show that coefficients of cash holdings are statistically significant across model 1-5, indicating target adjustment behaviour of Scandinavian firms. It is noticeable that the coefficient on 'financial deficit' is significantly positive, however, the sample mean is comparatively low e.g. (0.011). Moreover, the R-squared of the financial deficit (financial hierarchy model) is just (0.04), indicating a less significant relevance of financial hierarchy model with cash holdings adjustments compared to the trade-off model which shows the higher level ofRsquared ranging between (0.29) and (0.61) in column 1-5. Taken together, the results of robustness test substantiate that Scandinavian firms are better described by the trade-off theory compared to financial hierarchy theory and adjust the cash balance towards an optimal level of cash holdings for the precautionary motive. Based on these findings we accept the hypothesis $H 1$.

\subsection{Country-specific effects on cash holdings}

To shed more light on the evidence whether sample firms cash holdings have significant country-specific effects we present the country level cross-sectional estimates of Denmark, Norway and Sweden in Table 4. Denmark is taken as a base country for the analysis being the smallest sample of the pooled observations. Column 1 presents the results of pooled OLS which incorporate country dummies, industry dummies and firm-specific characteristics which indicates that firms' cash ratios significantly change across countries. These results suggest a substantial country-level heterogeneity indicating that cash holdings of sample firms have significant country-specific attributes. In addition, the estimated coefficient on Sweden is positively significant at $1 \%$ level suggesting that Swedish firms are better defined by trade-off theory while Norway dummy is insignificant indicating that cash holdings approach of Norwegian firms is supported by financial hierarchy theory. Moreover, the regression result shows that the average difference in firms' cash holdings between Denmark and Sweden is 5\%. This evidence is consistent with the cash ratios reported in Table 1. The regression analysis further shows that Scandinavian firms cash holdings increase with higher Tobin's Q, cash flow, dividend and industry sigma (cash flow volatility) and decrease with higher leverage and capital expenditure. The positive coefficient on cash flow volatility indicates that Scandinavian firms with a higher level of volatile cash flows prefer to hold larger cash to minimise the estimated cost of liquidity constraints. The significant negative coefficient on leverage supports the argument that firms external borrowing can be considered a substitute for cash holdings while NWC and firms size remain 
Table 4 Cash holdings and firms' specific factors with country dummies (Heterogeneity)

\begin{tabular}{|c|c|c|c|c|}
\hline & Pooled & Denmark & Norway & Sweden \\
\hline Tobin's Q & $\begin{array}{l}0.832 * * \\
(0.799)\end{array}$ & $\begin{array}{c}0.641 * \\
(0.090)\end{array}$ & $\begin{array}{l}0.686^{* *} \\
(0.449)\end{array}$ & $\begin{array}{l}0.641 * * \\
(0.041)\end{array}$ \\
\hline Leverage & $\begin{array}{c}-0.013 * * * \\
(0.169)\end{array}$ & $\begin{array}{c}-0.854 * \\
(0.058)\end{array}$ & $\begin{array}{c}-0.376 * * * \\
(0.023)\end{array}$ & $\begin{array}{c}-0.427 * * \\
(0.254)\end{array}$ \\
\hline NWC/Assets & $\begin{array}{c}0.586 \\
(0.094)\end{array}$ & $\begin{array}{c}0.677 \\
(0.787)\end{array}$ & $\begin{array}{r}-0.533 \\
(2.679)\end{array}$ & $\begin{array}{r}-0.422 \\
(0.054)\end{array}$ \\
\hline Cash flow & $\begin{array}{l}0.563 * \\
(0.289)\end{array}$ & $\begin{array}{l}0.145^{*} \\
(1.142)\end{array}$ & $\begin{array}{c}0.629 * \\
(0.231)\end{array}$ & $\begin{array}{c}0.602 \\
(0.645)\end{array}$ \\
\hline Capital exp & $\begin{array}{c}-0.606^{* * * *} \\
(0.604)\end{array}$ & $\begin{array}{c}-0.010 * * \\
(0.218)\end{array}$ & $\begin{array}{l}0.557 * * * \\
(0.449)\end{array}$ & $\begin{array}{c}-0.608^{*} \\
(0.204)\end{array}$ \\
\hline Firm size & $\begin{array}{c}0.185 \\
(0.231)\end{array}$ & $\begin{array}{c}0.964 \\
(0.319)\end{array}$ & $\begin{array}{c}0.912 \\
(0.947)\end{array}$ & $\begin{array}{c}0.199 \\
(0.443)\end{array}$ \\
\hline Dividend dummy & $\begin{array}{l}0.140 * * \\
(0.018)\end{array}$ & $\begin{array}{c}0.831 * \\
(0.314)\end{array}$ & $\begin{array}{l}0.611 * \\
(0.111)\end{array}$ & $\begin{array}{l}0.516^{* * *} \\
(0.204)\end{array}$ \\
\hline Industry sigma & $\begin{array}{l}0.616^{* * * *} \\
(0.79)\end{array}$ & $\begin{array}{l}0.107 * \\
(0.063)\end{array}$ & $\begin{array}{c}0.052 * \\
(0.154)\end{array}$ & $\begin{array}{l}0.555^{* *} \\
(0.613)\end{array}$ \\
\hline Norway & $\begin{array}{c}0.070 \\
(0.235)\end{array}$ & & & \\
\hline Sweden & $\begin{array}{l}0.050 * * * \\
(0.137)\end{array}$ & & & \\
\hline $\mathrm{N}$ & 11,842 & 2073 & 2545 & 7224 \\
\hline Constant & $\begin{array}{l}0.18 * * \\
(0.01)\end{array}$ & $\begin{array}{l}0.24 * * * \\
(0.07)\end{array}$ & $\begin{array}{l}0.11 * * * \\
(0.03)\end{array}$ & $\begin{array}{l}0.29 * * \\
(0.04)\end{array}$ \\
\hline R-squared & 0.33 & 0.39 & 0.29 & 0.26 \\
\hline Adjusted R-squared & 0.26 & 0.31 & 0.21 & 0.19 \\
\hline
\end{tabular}

This table presents the country level cross-sectional results across Denmark, Norway and Sweden. Denmark is taken as a base country for the analysis being the smallest sample of the pooled observations. Column 1 presents the results of pooled OLS which incorporate country dummies, industry dummies and firm-specific characteristics, indicates that firms cash ratios significantly change across countries. Column $2-4$ present estimation of the country-specific attribute to capture heterogeneity across countries

$* * *, * *$ and $*$ Indicate coefficients are significant at the 1,5 and $10 \%$ level, respectively

insignificant in determining firms level cash holdings which is inconsistent with the argument that large-size firms tend to hold larger amounts of cash. We argue that the possibility of financial distress is linked with leverage which induces professional manager to maintain excess cash holdings at higher leverage level to reduce the risk of bankruptcy.

\subsection{Dynamic cash holdings model}

Acharya et al. (2007) argue that cash holdings regression based on firms' level variables suffer inherited endogeneity as there is a possibility that cash holdings and firms' debt may determine jointly. Likewise, Opler et al. (1999) report that variable which influences cash holdings may also be inversely affected by firms' level of debts. Moreover, it is well documented that the presence of endogeneity makes the estimation biased and inconsistent (see, 
for example, Akbar et al. 2016; Ramadan El-Faitouri 2014; Wintoki et al. 2012). Accordingly, the present study investigates the firms' partial adjustment process towards the cash target by estimating a dynamic panel GMM to control potential source of endogeneity. Accordingly, the following model is developed:

$$
\mathrm{Cash}_{\mathrm{it}+1}-\mathrm{Cash}_{\mathrm{it}}=\alpha+\lambda\left(\mathrm{Cash}_{\mathrm{it}}^{*}-\mathrm{Cash}_{\mathrm{it}}\right)+v i+\varepsilon_{\mathrm{it}}
$$

where cash denotes the firm cash holdings while cash ${ }^{*}$ represents the estimated cash target. In addition, the present study examines the target cash levels by considering the firms' characteristics and develop the following equation:

$$
\left.\operatorname{Cash}_{\mathrm{it}+1}^{*}=\alpha+\sum_{k}(\beta \lambda) \mathrm{X}_{\mathrm{k}, \mathrm{it}}\right)+v i+\varepsilon_{\mathrm{it}}
$$

where $X_{k, i t}$ represents the vector of firms' characteristics. In addition, following Opler et al. (1999) we substitute Eq. (5) into Eq. (6) and develop the following dynamic estimation:

$$
\left.\operatorname{Cash}_{\mathrm{it}+1}^{*}=\alpha+(1-\lambda) \operatorname{Cash}_{\mathrm{it}}+\sum_{k}(\beta \lambda) \mathrm{X}_{\mathrm{k}, \mathrm{it}}\right)+\delta 0_{\mathrm{it}+1}+\varepsilon_{\mathrm{it}}
$$

The Eq. (7) indicates that tend to minimise the difference between expected cash levels $\left(\beta \mathrm{X}_{\mathrm{k}, \mathrm{it}}\right)$ and actual cash level $\left(\mathrm{Cash}_{\mathrm{it}}\right)$. Moreover, based on Eq. (7) we estimate a two-steps GMM model which develops a system of two simultaneous equations including one in levels and the other in first difference. The GMM estimator allows to account for dynamics of the cash holdings and address the econometric issues such as endogeneity and simultaneity which are associated with panel data estimation. Furthermore, the GMM estimator allows us to use the lagged dependent variable and explanatory variables as instruments. We estimate the model with two different specifications namely, $G M M^{a}$ and $G M M^{b}$. In the first model i.e. $G M M^{a}$ following prior studies such as Wintoki et al. (2012) and Ozkan and Ozkan (2004), we treat all variables as endogenous except year dummies and use their lags of two or more periods as instruments. In the second model i.e. $G M M^{b}$ we consider all variables as exogenous except those which are strictly endogenous (see, for example, Akbar et al. 2016; Ozkan and Ozkan 2004). Column 1 and 2 of Table 5 presents the results of OLS and fixed effects estimation while column 3 and 4 shows the findings of dynamic GMM model e.g. $G M M^{a}$ and $G M M^{b}$ for the full sample by estimating Eq. (7). Column 5-13 presents the results of OLS, fixed effects and GMM estimator across individual samples e.g. Demark, Norway and Sweden. Column 1 and 2 shows that the coefficients on the cash holdings of OLS and fixed effects estimation are (0.588) and (0.497) while SOA is $(0.412)$ and (0.501) respectively, indicating that on average, Scandinavian firms' cover half of their cash level adjustment ranging between (1.682) and (1.386) years. In addition, these findings show that sample firms actively adjust their cash level towards the target. Column 3 shows that $p$ value of Arellano and Bond AR (2) of $G M M^{a}$ is sufficiently high at $(0.456)$ therefore, the null hypothesis of instruments validity cannot be rejected. In a related vein, the $p$ value of the Hansen test is also high at $(0.521)$ thus the null hypothesis that instruments as a group are exogenous cannot be rejected. Moreover, AR (2) and Hanson tests of individual samples e.g. Denmark, Norway and Sweden are also high such as (0.321), (0.467), and (0.966), (0.456), (0.332) and (0.711) respectively, which validate the strength of GMM estimator. On the other hand, AR (2) of $G M M^{b}$ is statically significant (0.043), therefore, the null hypothesis of instruments validity is rejected while the $p$ value of Hansen test is sufficiently high (0.571) thus the null hypothesis that instruments 


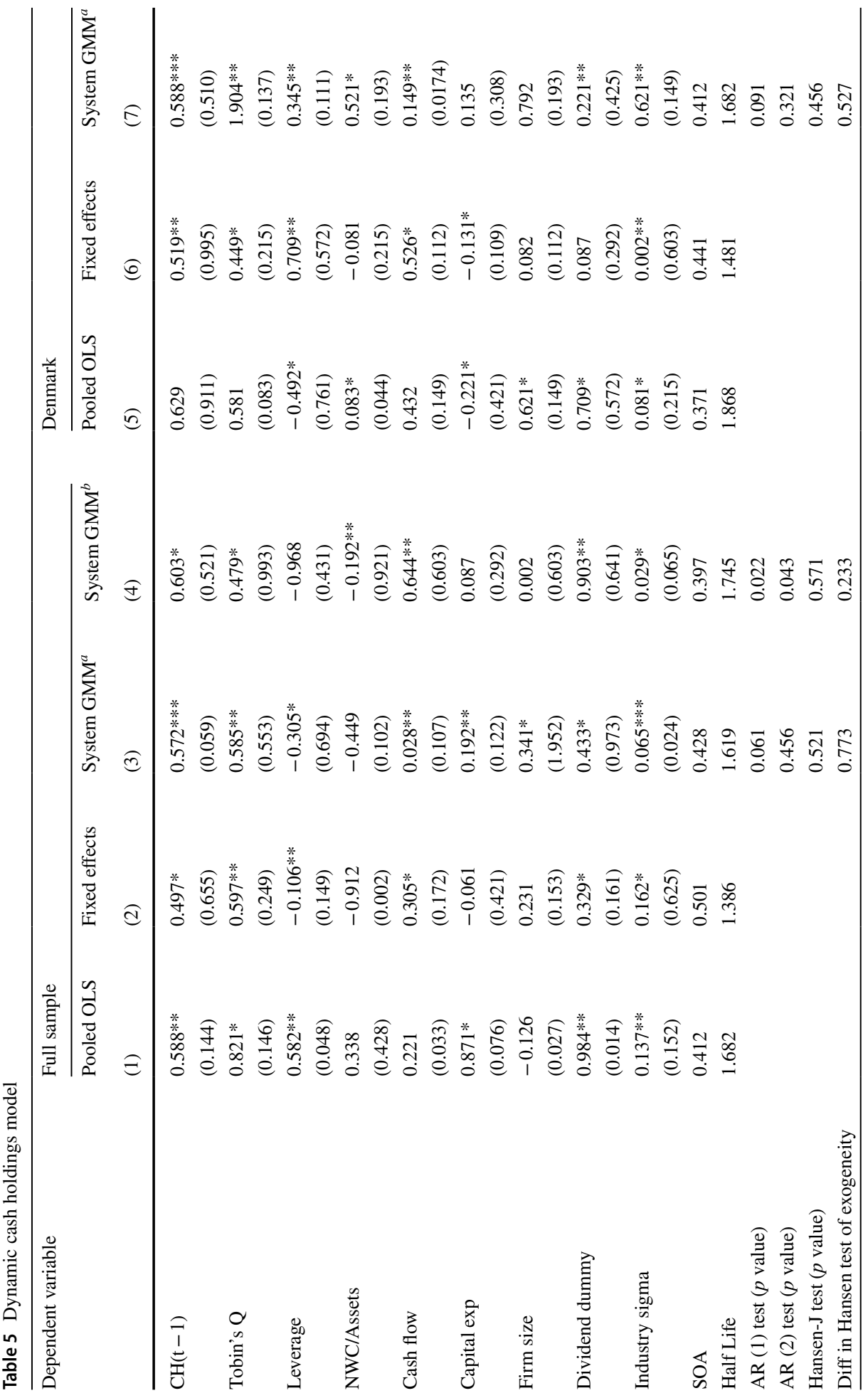




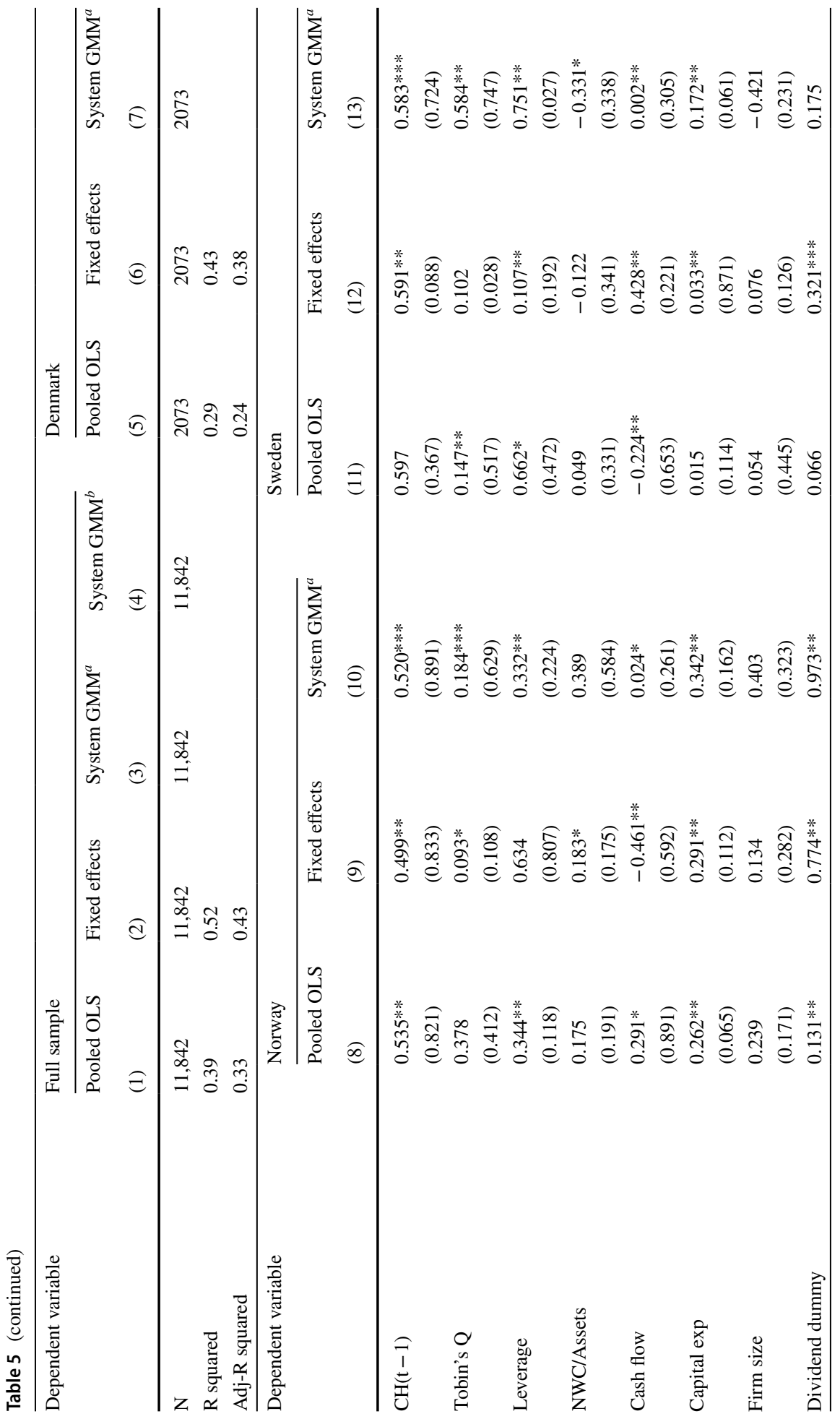




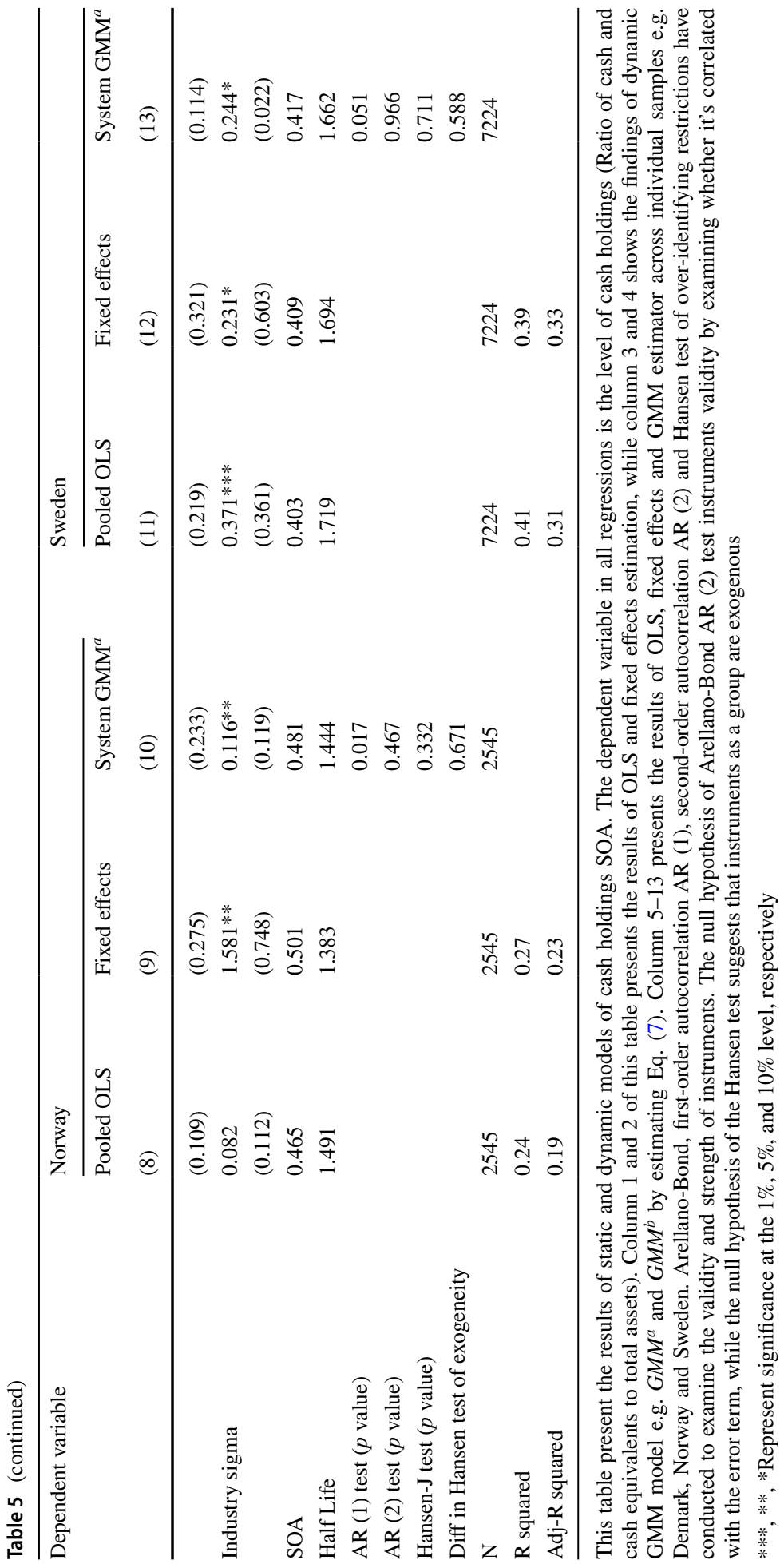


as a group are exogenous cannot be rejected. The $G M M^{a}$ estimator better satisfied the assumptions of dynamic panel GMM as it fixed the autocorrelation and over-identification restrictions more efficiently compared to $G M M^{b}$ and substantiate the health of instruments (J-statistics). We, therefore, discuss the findings of $G M M^{a}$ and compare its results with pooled OLS and fixed effects models. In addition, the $G M M^{a}$ estimator results in column 3 show that the coefficient on the lagged dependent variable is $(0.572)$ while SOA and halflife period are (0.428) and (1.619 years), respectively. These results show that the SOA of Scandinavian firms is significantly lower than US firms (0.540) document by Orlova and Rao (2018) while it's marginally close to the global sample of Dittmar and Duchin (2010) who report SOA ranging between $(0.353)$ and $(0.433) .^{2}$

Furthermore, GMM estimator results indicate that the SOA of individual samples e.g., Denmark, Norway and Sweden are (0.412), (0.481), (0.417), respectively while half-life periods are (1.682), (1.444), and (1.662) years, respectively. More specifically, the SOA of Norwegian firms (0.481) significantly greater than Danish (0.412) and Swedish firms (0.417), indicating that the adjustment costs and off-target costs of Norwegian firms are marginally close to each other which lead to quicker deviation towards the target. In addition, the stable cash holdings level of Norwegian firms leads to a faster SOA as reported in Table 1. Moreover, the half-life period of Norwegian firms is significantly shorter than other samples, validating its quicker SOA and stable cash holdings levels compared to other samples.

Additionally, Bond (2002) reveals that accurate and consistent estimation of lagged dependent variable generally lies somewhere between the ordinary least square and fixed effects estimations. Our results provide interesting insights as the estimated coefficient on $G M M^{a}$ of full sample (0.572), lies between the estimated coefficient on pooled OLS (0.588) and fixed effects model (0.497) which is corroborated with Bond (2002) prediction. This evidence indicates that Scandinavian firms rebalance their cash holdings by dynamic adjustment toward the cash target.

\subsection{Estimation of cross-sectional variation in SOA}

We extend our analysis by examining the cross-sectional variation in cash holdings level to determine whether SOA is heterogeneous across Scandinavian firms and presents the results in Table 6. In the next lines analysis, we present substantial evidence of heterogeneity in SOA based on six factors such as high cash, medium cash, low cash level, active/ passive cash management, use of leverage financing and the level of investment opportunities. At first, we classified firms based on the relatively high, medium and low level of excess cash. We examine whether SOA is associated with the different level of cash holdings which leads to the different levels of adjustment cost and off-target cost. The excess cash is determined as (Cash-Cash ${ }^{*}$, while Cash ${ }^{*}$ is estimated by following fixed effects estimation of Opler et al. (1999). Moreover, following Dittmar and Duchin (2010) dummy variables are generated with three different classifications i.e. high, medium and low cash level and interact with the lagged dependent variable specified in Eq. 7. For example, the

\footnotetext{
2 The coefficient on $\lambda$ captures the magnitude of the difference between target and actual cash levels that typical firms generally close each year. Following prior studies, we determine SOA $(\lambda)$ by subtracting the estimated coefficient $(\delta 0)$ on the lagged cash holdings from 1 (e.g., $1-\delta 0)$. Moreover, the estimates of SOA are explained in terms of the half-life period which is defined as the time required to cover half of the distance from opening balance of cash to the target level.
} 
Table 6 Estimation of cross-sectional variation in SOA

\begin{tabular}{|c|c|c|c|c|c|}
\hline Dependent variable & $\begin{array}{l}\text { EX-Cash } \\
\text { (1) }\end{array}$ & $\begin{array}{l}\text { EX-Cash (Ind) } \\
\text { (2) }\end{array}$ & $\begin{array}{l}\text { Active } \\
\text { (3) }\end{array}$ & $\begin{array}{l}\text { Leverage } \\
\text { (4) }\end{array}$ & $\begin{array}{l}\text { Investment } \\
\text { (5) }\end{array}$ \\
\hline High cash-dummy & $\begin{array}{l}0.498 * * * \\
(0.342)\end{array}$ & $\begin{array}{l}0.529 * * \\
(0.224)\end{array}$ & $\begin{array}{l}0.561 * * \\
(0.347)\end{array}$ & $\begin{array}{l}0.503 * \\
(0.521)\end{array}$ & $\begin{array}{l}0.561 * * \\
(0.055)\end{array}$ \\
\hline Medium cash-dummy & $\begin{array}{l}0.603 * * * \\
(0.965)\end{array}$ & $\begin{array}{l}0.587 * * * \\
(0.432)\end{array}$ & $\begin{array}{l}0.619 * \\
(0.251)\end{array}$ & $\begin{array}{l}0.621 * * * \\
(0.234)\end{array}$ & $\begin{array}{l}0.603 * * \\
(0.641)\end{array}$ \\
\hline Low cash-dummy & $\begin{array}{l}0.641 * * \\
(0.831)\end{array}$ & $\begin{array}{l}0.704 * * * \\
(0.289)\end{array}$ & $\begin{array}{l}0.659 * * * \\
(0.027)\end{array}$ & $\begin{array}{l}0.657 * * * \\
(0.328)\end{array}$ & $\begin{array}{l}0.703 * * * \\
(0.637)\end{array}$ \\
\hline Tobin's Q & $\begin{array}{l}0.383 * * \\
(0.719)\end{array}$ & $\begin{array}{l}0.646^{*} \\
(0.094)\end{array}$ & $\begin{array}{l}0.084 * * \\
(0.403)\end{array}$ & $\begin{array}{l}0.311 * * \\
(0.385)\end{array}$ & $\begin{array}{l}0.621 * * \\
(0.244)\end{array}$ \\
\hline Leverage & $\begin{array}{l}-0.805^{*} \\
(0.487)\end{array}$ & $\begin{array}{l}-0.454 * * \\
(0.058)\end{array}$ & $\begin{array}{l}-0.052^{* * * *} \\
(0.201)\end{array}$ & $\begin{array}{l}-0.292^{* * * *} \\
(0.599)\end{array}$ & $\begin{array}{l}-0.439 * * \\
(0.141)\end{array}$ \\
\hline NWC/Assets & $\begin{array}{l}-0.172 \\
(0.029)\end{array}$ & $\begin{array}{l}-0.677 * \\
(0.787)\end{array}$ & $\begin{array}{l}-0.115 \\
(0.221)\end{array}$ & $\begin{array}{l}0.012 \\
(0.127)\end{array}$ & $\begin{array}{l}-0.553 * * \\
(0.261)\end{array}$ \\
\hline Cash flow & $\begin{array}{l}0.104 * * * \\
(0.399)\end{array}$ & $\begin{array}{l}-0.187 * * \\
(0.059)\end{array}$ & $\begin{array}{l}0.421 \\
(0.261)\end{array}$ & $\begin{array}{l}0.142 * * \\
(0.145)\end{array}$ & $\begin{array}{l}0.094 * * * \\
(0.245)\end{array}$ \\
\hline Capital exp & $\begin{array}{l}-0.225^{* *} \\
(0.283)\end{array}$ & $\begin{array}{l}-0.486^{*} \\
(0.118)\end{array}$ & $\begin{array}{l}-0.984 \\
(0.134)\end{array}$ & $\begin{array}{l}0.016 * * \\
(0.096)\end{array}$ & $\begin{array}{l}0.261 * \\
(0.651)\end{array}$ \\
\hline Firm size & $\begin{array}{l}0.152 \\
(0.725)\end{array}$ & $\begin{array}{l}0.432 \\
(0.375)\end{array}$ & $\begin{array}{l}-0.281 \\
(0.056)\end{array}$ & $\begin{array}{l}0.001 \\
(0.638)\end{array}$ & $\begin{array}{l}0.116^{* * *} \\
(0.414)\end{array}$ \\
\hline Dividend dummy & $\begin{array}{l}1.375^{*} \\
(0.191)\end{array}$ & $\begin{array}{l}0.251 * * * \\
(0.046)\end{array}$ & $\begin{array}{l}0.019 * * \\
(0.312)\end{array}$ & $\begin{array}{l}0.214 * * \\
(0.099)\end{array}$ & $\begin{array}{l}0.477 * * * \\
(0.331)\end{array}$ \\
\hline Industry sigma & $\begin{array}{l}0.025^{*} \\
(0.256)\end{array}$ & $\begin{array}{l}0.216 * * \\
(0.451)\end{array}$ & $\begin{array}{l}0.131 * * \\
(0.161)\end{array}$ & $\begin{array}{l}0.324 * * \\
(0.461)\end{array}$ & $\begin{array}{l}0.482 * \\
(0.183)\end{array}$ \\
\hline SOA (high cash firm) & 0.502 & 0.471 & 0.439 & 0.497 & 0.439 \\
\hline SOA (medium cash firm) & 0.397 & 0.413 & 0.381 & 0.379 & 0.397 \\
\hline SOA (low cash firm) & 0.359 & 0.296 & 0.341 & 0.343 & 0.297 \\
\hline $\mathrm{N}$ & 11,842 & 11,842 & 11,842 & 11,842 & 11,842 \\
\hline AR (1) test ( $p$ value) & 0.321 & 0.041 & 0.673 & 0.832 & 0.09 \\
\hline AR (2) test ( $p$ value) & 0.673 & 0.735 & 0.234 & 0.567 & 0.603 \\
\hline Hansen-J test ( $p$ value) & 0.567 & 0.754 & 0.145 & 0.367 & 0.621 \\
\hline Difference in hansen test & 0.371 & 0.256 & 0.431 & 0.367 & 0.563 \\
\hline
\end{tabular}

This table presents the cross-sectional variation in SOA with the estimation of dynamic GMM estimator. Following Dittmar and Duchin (2010), the dummy variables are generated with three different classifications i.e. high, medium and low cash level, and interact with the lagged dependent variable in Eq. 7. For example, the firm-years with excess cash e.g. (high cash dummy =1), includes those firms which have high cash in the top third of the sample, while firm-years with medium level excess cash e.g. (medium cash dummy $=1$ ), includes those firms which are ranked in the middle third of the observations. The bottom third of the observations with the low-level cash level e.g. (low cash dummy=1) is defined as low cash firms and present the result in column 1. Column 2 shows median of industry level cash to determine firms target level of cash holdings by taking high excess cash firms (high cash dummy =1), medium excess cash firms (medium cash dummy =1), and low excess cash firms (low cash dummy =1), respectively, e.g. those firms whose cash levels are above or below the industry median, respectively, while the observations having neither too high nor too low cash level, are treated as medium cash firms. Column 4-6 shows the estimation of SOA where the firms are involved in making a dividend payment, use of debt finance and by engaging in greater investment level, respectively with the classification of high, medium and low level 
firm-years with excess cash e.g. (high cash dummy $=1$ ), includes those firms which have high cash in the top third of the sample. Likewise, firm-years with medium level excess cash e.g. (medium cash dummy=1), includes those firms which are ranked in the middle third of the observations. Finally, the bottom third of the observations with the low-level cash level e.g. (low cash dummy $=1$ ) is defined as low cash firms. We expect a slow SOA to the cash deficit firms which is associated with higher adjustment cost owing to the financial frictions. Column 1 of Table 6 shows the results of GMM estimator which determine cash level deviation towards the target. The results show that high excess cash firms associate with higher SOA $(0.502=1-0.498)$ compared to the firms with low excess cash firms $(0.359=1-0.641)$. These findings show that it's costlier for low cash firms to rebalance their cash levels towards target compared to high cash firms. These results are corroborated with the firms' behaviour observed in Fig. 1 which demonstrate that the high excess cash firms tend to reduce their cash holdings level while the low cash and cash deficit firms increase their cash balance, however, excess cash firms increase their cash level more than the decrease in cash level by cash deficit firms. These findings validate the hypothesis $\mathrm{H}_{2}$ that difference in cash levels and adjustment costs among firms lead to different levels of SOA. Column 2 shows median of industry-level cash to determine firms target level of cash holdings by taking high excess cash firms (high cash dummy =1) and low excess cash firms (low cash dummy $=1$ ), respectively e.g. those firms whose cash levels are above or below the industry median, respectively while the observations having neither too high nor too low cash level are treated as medium cash firms e.g. (medium cash dummy =1). In the next step, we interact these dummy variables with the lagged dependent variable in Eq. (7) and present the results in column 2. The findings demonstrate that firms with high excess cash than industry median show greater SOA $(0.471=1-0.529)$ compared to low excess cash firms $(0.296=1-0.704)$. These findings substantiate that high adjustment cost of low cash firms and cash deficit firms slow down their SOA compared to high cash firms.

Going forward, we endeavour to examine how actively Scandinavian firms adjust their cash levels by using debt financing and the higher level of investment opportunities. We, therefore, first examine the change in firms' excess cash holdings:

$$
\mathrm{EX}_{-} \mathrm{Cash}_{\mathrm{it}}-\mathrm{EX}_{-} \mathrm{Cash}_{\mathrm{it}-1}=\alpha+\left(\mathrm{Cash}_{\mathrm{it}}^{*}-\mathrm{Cash}_{\mathrm{it}}\right)-\left(\mathrm{Cash}_{\mathrm{it}-1}^{*}-\mathrm{Cash}_{\mathrm{it}-1}\right)
$$

where 'cash' is the firms' cash holdings while cash" is representing the estimate of cash holdings target, EX_Cash is excess cash holdings estimated by following fixed effects estimator of Opler et al. (1999). Moreover, by rearranging Eq. 8 we develop fowling equation:

$$
\mathrm{EX} \_C a s h_{\mathrm{it}}-{\mathrm{EX} \_C a s h_{\mathrm{it}-1}}=\alpha+\left(\mathrm{Cash}_{\mathrm{it}}^{*}-\mathrm{Cash}_{\mathrm{it}-1}^{*}\right)-\left(\mathrm{Cash}_{\mathrm{it}-1}-\mathrm{Cash}_{\mathrm{it}}\right)
$$

In addition, following the seminal study by Dittmar and Duchin (2010), we describe the following equations:

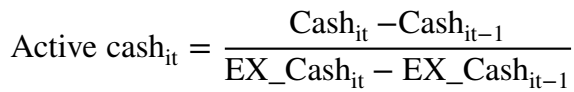

$$
\begin{aligned}
& \text { Passive } \operatorname{cash}_{\mathrm{it}}=\frac{\mathrm{Cash}_{\mathrm{it}}^{*}-\mathrm{Cash}_{\mathrm{it}-1}^{*}}{\mathrm{EX}_{-} \mathrm{Cash}_{\mathrm{it}}-\mathrm{EX}_{-} \text {Cash }_{\mathrm{it}-1}}
\end{aligned}
$$

'Active' represents the measurement of the change in firms unexpected cash holdings characteristics towards the change in the actual cash level while 'Passive' denotes the 
measurement of adjustment in unexpected cash holdings as a result of the change in cash holdings target. Following Eq. (9a) and (9b) we develop a dummy variable which is equal to 1 if Active $_{\text {it }}>$ Passive $_{i t}$ and 0 otherwise, to determine how actively a firm manages its cash levels. The analysis shows that $81 \%$ of the sample observations relate to the Active group, indicating that the majority of sample firms tend to actively adjust their cash levels. Next, we interact the dummy variables with the lagged dependent variable in Eq. (7) and estimate whether Scandinavian firms are actively managing the cash holdings. Column 3 shows that SOA differs across sub-groups e.g. Active and Passive cash management. The findings reveal that the firms with Active cash management display higher SOA $(0.439=1-0.561)$ compared with those who do not actively rebalance their cash holdings i.e. low cash firms $(0.341=1-0.659)$. Therefore, these findings demonstrate that active cash holdings management associated with the firms' higher SOA and lower adjustment costs.

Moreover, following Dittmar and Duchin (2010), we further investigate whether firms actively rebalance their cash levels in the case of leverage finance and greater investment level. In column 4 and 5, we categorise firms based on leverage ratios, defined as the ratio of total debts scaled by total assets and firms' investment, measured as capital expenditure to total assets, respectively. Further, we categorised firms as (high-dummy=1), medium (medium-dummy $=1)$, and low (low-dummy $=1$ ) levels of debts ratio and investment in the given year, in the top, medium and bottom third of industry average mean, respectively and interact these dummy variables with lagged dependent variable based on Eq. (7).

The findings in columns 4-5 demonstrate that SOA of firms with higher leverage finance and with greater investment level are (0.497) and (0.439), respectively, which are faster than the SOA of lower leverage finance firms (0.343) and small investment firms (0.297). The potential explanation of these findings is that the professional managers need to accommodate debts re-payments and future investment needs, therefore, they required higher cash level with faster SOA towards the target cash holdings. These findings substantiate that SOA is heterogeneous across sample firms which corroborated with the study results of Dittmar and Duchin (2010).

\subsection{Impact of financial constraints on SOA}

To gain further insight into the factors affecting SOA, we examine cash holding SOA across FC and UC firms by categorizing firm-years observations based on four indices i.e. dividend payment, firm size, growth and interest coverage ratio and present the results in Table 7. Panel A of Table 7 demonstrates the cross-classification of firm-years observations indicating that there are (8715), (7469), (7091), and (6470) firms-years of FC firms across four constraints criteria respectively while (3127), (4373), (4751), and (5372) firmyears of UC firms respectively. In addition, panel B of Table 7 presents yearly cash holdings across FC and UC firms. The mean cash holdings of FC firms are ranging between 13.1 and $14.9 \%$ while cash holdings are varying between 10.5 and $12.3 \%$ for UC firms across different constraints indices indicating that FC firms have higher cash holdings than UC firms.

We further examine the effectiveness of firms' cash management policies against financial constraints by categorizing firms based on four different constraints indices and determine their impact on SOA. Column 1 and 2 of Table 8 shows that the estimated coefficient on FC and UC firms based on dividend criteria is (0.557) and (0.633) respectively while the SOA of FC firms (0.443) is faster than the SOA (0.367) of UC firms, consequently, the 
Table 7 Financial constraint criteria

\begin{tabular}{|c|c|c|c|c|c|c|c|c|}
\hline \multirow[t]{2}{*}{ Cash holdings } & \multicolumn{2}{|c|}{ Dividend } & \multicolumn{2}{|c|}{ Firm size } & \multicolumn{2}{|c|}{ Growth } & \multicolumn{2}{|c|}{$\begin{array}{l}\text { Interest cover- } \\
\text { age }\end{array}$} \\
\hline & $\mathrm{FC}$ & UC & $\mathrm{FC}$ & UC & $\mathrm{FC}$ & UC & $\mathrm{FC}$ & UC \\
\hline
\end{tabular}

Panel A. Cross classification of constraint allocation

(1) Dividend payment

Constrained firms (FC) $\quad 8715$

Unconstrained firms (UC) 3127

(2) Firm size

$\begin{array}{llll}\text { Constrained firms (FC) } & 5996 & 1473 & 7469\end{array}$

Unconstrained firms (UC) $2719 \quad 1654$

(3) Growth

$\begin{array}{lllllll}\text { Constrained firms (FC) } & 5427 & 1664 & 4609 & 2482 & 7091 & \\ \text { Unconstrained firms (UC) } & 3288 & 1463 & 2860 & 1891 & & 4751\end{array}$

(4) Interest coverage

\begin{tabular}{|c|c|c|c|c|c|c|c|}
\hline Constrained firms (FC) & 4465 & 2005 & 4189 & 2281 & 4175 & 2295 & 6470 \\
\hline Unconstrained firms (UC) & 4250 & 1122 & 3280 & 2092 & 2916 & 2456 & 5372 \\
\hline Cash holdings & & $\mathrm{N}$ & & Mean & & Median & SD \\
\hline
\end{tabular}

Panel B. Summary statistics of cash holdings across constraint criteria

(1) Dividend payment

\begin{tabular}{lllll} 
Constrained firms (FC) & 8715 & 0.146 & 0.095 & 0.178 \\
Unconstrained firms (UC) & 3127 & 0.108 & 0.072 & 0.131 \\
$\begin{array}{l}\text { 2) Firm size } \\
\text { Constrained firms (FC) }\end{array}$ & 7469 & 0.142 & 0.092 & 0.152 \\
Unconstrained firms (UC) & 4373 & 0.112 & 0.081 & 0.149 \\
3) Growth & & & 0.089 & 0.145 \\
Constrained firms (FC) & 7091 & 0.131 & 0.083 & 0.131 \\
Unconstrained firms (UC) & 4751 & 0.123 & & 0.151 \\
(4) Interest coverage & & & 0.098 & 0.113 \\
Constrained firms (FC) & 6470 & 0.149 & 0.07 & \\
Unconstrained firms (UC) & 5372 & 0.105 & & \\
\hline
\end{tabular}

Panel A of this table shows the firms yearly cross-classification for the four constraints criteria i.e. dividend, size, growth and interest coverage ratio to categorize firms as financially constrained or unconstrained. Panel B reports the summary statics of cash holdings across financially constrained and unconstrained firms. The sample firms include non-financial listed firms of France and German firms over the period 2000-2016

half-life period of FC firms (1.564 years) is shorter than UC firms (1.888 years). Based on these findings we accept the hypothesis $\mathrm{H}_{2}$. The quicker SOA of FC firms indicates that professional managers hold larger cash to meet their precautionary motive and less concerned about profitable investment opportunities. In addition, we argue that FC firms endeavour to cover their transaction cost for unconditional liquidity thus behave more sensitive for optimal cash level. Therefore, FC firms quickly deviate their cash level towards the optimal cash holdings compared to UC firms. These findings validate the hypothesis: $\mathrm{H}_{2}$ 
Table 8 SOA's across financially constrained (FC) and unconstrained (UC) firms

\begin{tabular}{|c|c|c|c|c|c|c|c|c|}
\hline \multirow[t]{3}{*}{ Variables } & \multicolumn{2}{|c|}{ Dividend payment } & \multicolumn{2}{|l|}{ Firm size } & \multicolumn{2}{|l|}{ Growth } & \multicolumn{2}{|c|}{ Interest coverage } \\
\hline & $\mathrm{FC}$ & $\mathrm{UC}$ & $\mathrm{FC}$ & $\mathrm{UC}$ & $\mathrm{FC}$ & $\mathrm{UC}$ & $\mathrm{FC}$ & $\mathrm{UC}$ \\
\hline & (1) & (2) & (3) & (4) & (5) & (6) & (8) & (9) \\
\hline \multirow{2}{*}{$\begin{array}{l}\text { Cash hold- } \\
\text { ings }\end{array}$} & $0.557 * *$ & $0.633^{*}$ & $0.592 * *$ & $0.644^{* *}$ & $0.489 * * *$ & $0.551 * *$ & $0.504^{*}$ & $0.533^{* *}$ \\
\hline & $(0.576)$ & $(0.152)$ & $(0.054)$ & $(0.791)$ & $(0.231)$ & $(0.029)$ & $(2.679)$ & $(0.719)$ \\
\hline \multirow[t]{2}{*}{ Tobin's Q } & $0.433 * *$ & $0.725 * *$ & $0.602^{*}$ & $0.221 * *$ & $0.606 * * *$ & 0.522 & $0.965^{*}$ & $0.805^{*}$ \\
\hline & $(0.917)$ & $(0.35)$ & $(0.645)$ & $(0.102)$ & $(0.604)$ & $(0.427)$ & $(0.319)$ & $(0.487)$ \\
\hline \multirow[t]{2}{*}{ Leverage } & $-0.159 * *$ & -0.513 & -1.463 & $-0.521 * *$ & $-0.231^{*}$ & $-0.384 *$ & 0.831 & $-0.176^{* *}$ \\
\hline & $(4.358)$ & $(0.957)$ & $(1.868)$ & $(0.006)$ & $(0.249)$ & $(1.122)$ & $(0.314)$ & $(0.553)$ \\
\hline \multirow{2}{*}{$\begin{array}{l}\text { NWC/ } \\
\text { Assets }\end{array}$} & $-0.641 *$ & -0.592 & $-0.832 * *$ & $0.214 *$ & $-0.104 *$ & $-0.435^{* *}$ & $0.107 *$ & $-0.269 * *$ \\
\hline & $(0.094)$ & $(0.613)$ & $(0.799)$ & $(0.031)$ & $(0.136)$ & $(0.062)$ & $(0.063)$ & $(0.915)$ \\
\hline \multirow[t]{2}{*}{ Cash flow } & $0.854^{*}$ & $0.657 * *$ & $0.013^{*}$ & 0.365 & $0.776^{* *}$ & $0.108^{*}$ & $0.155^{* * * *}$ & $0.211^{*}$ \\
\hline & $(0.058)$ & $(0.104)$ & $(0.169)$ & $(0.137)$ & (1.174) & $(0.895)$ & $(0.842)$ & (7.106) \\
\hline \multirow[t]{2}{*}{ Capital exp } & $-0.586^{* *}$ & $-0.137 * *$ & 3345 & $-0.191 *$ & $-0.155^{* *}$ & $-0.297 * *$ & $-0.233 * * *$ & 0.654 \\
\hline & $(0.094)$ & $(3.771)$ & $(0.947)$ & $(0.025)$ & $(0.268)$ & $(0.898)$ & $(0.7 .44)$ & $(0.348)$ \\
\hline \multirow[t]{2}{*}{ Firm size } & $0.563^{*}$ & $0.616^{* *}$ & $0.185 * *$ & $0.521 *$ & 0.125 & 0.611 & 0.733 & -0.617 \\
\hline & $(0.289)$ & $(0.204)$ & $(0.231)$ & $(0.271)$ & $(0.403)$ & $(0.111)$ & $(0.235)$ & $(0.201)$ \\
\hline \multirow{2}{*}{$\begin{array}{r}\text { Dividend } \\
\text { dummy }\end{array}$} & $0.686^{* *}$ & $0.324 * *$ & $0.140 * *$ & 0.543 & $0.111^{*}$ & $0.052 *$ & $0.575^{*}$ & 0.118 \\
\hline & $(0.449)$ & $(0.104)$ & $(0.018)$ & $(0.583)$ & $(0.431)$ & $(0.154)$ & $(0.576)$ & $(0.322)$ \\
\hline \multirow{2}{*}{$\begin{array}{r}\text { Industry } \\
\text { sigma }\end{array}$} & $-0.876^{*}$ & $0.399 *$ & $0.616 * * *$ & -0.054 & $0.384 * *$ & $0.048^{*}$ & $0.094 *$ & 0.347 \\
\hline & $(0.023)$ & $(3.225)$ & $(0.791)$ & $(2.427)$ & $(0.521)$ & $(0.111)$ & $(0.042)$ & $(0.362)$ \\
\hline $\mathrm{N}$ & 8715 & 3127 & 7469 & 4373 & 7091 & 4751 & 6470 & 5372 \\
\hline Wald f-stat & 2.085 & 3.651 & 1.196 & 4.024 & 5.393 & 2.251 & 3.262 & 4.571 \\
\hline SOA & 0.443 & 0.367 & 0.408 & 0.356 & 0.511 & 0.449 & 0.496 & 0.467 \\
\hline Half Life & 1.564 & 1.888 & 1.698 & 1.947 & 1.356 & 1.543 & 1.397 & 1.484 \\
\hline $\begin{array}{r}\mathrm{AR}(1) \text { test } \\
\quad(p \text { value })\end{array}$ & 0.041 & 0.432 & 0.543 & 0.734 & 0.092 & 0.063 & 0.022 & 0.062 \\
\hline $\begin{array}{r}\mathrm{AR}(2) \text { test } \\
\quad(p \text { value })\end{array}$ & 0.462 & 0.632 & 0.436 & 0.673 & 0.332 & 0.441 & 0.354 & 0.463 \\
\hline $\begin{array}{l}\text { Hansen-J } \\
\text { test }\end{array}$ & 0.514 & 0.463 & 0.882 & 0.115 & 0.517 & 0.463 & 0.328 & 0.833 \\
\hline $\begin{array}{l}\text { Diff in } \\
\text { Hansen } \\
\text { test }\end{array}$ & 0.221 & 0.431 & 0.819 & 0.192 & 0.225 & 0.422 & 0.526 & 0.391 \\
\hline
\end{tabular}

This table present the estimation of SOA across financially constrained and unconstrained firms based on four constraint criteria e.g. dividend, size, growth and interest coverage ratio. All model estimations based on two-step system GMM estimator. Arellano-Bond, first-order autocorrelation AR (1), second-order autocorrelation AR (2) and Hansen test of over-identifying restrictions have conducted to examine the validity and strength of instruments. The null hypothesis of Arellano-Bond AR (2) test instruments validity by examining whether it's correlated with the error term, while the null hypothesis of the Hansen test suggests that instruments as a group are exogenous. Wald f-statistic reflect the difference in the coefficient across different groups

$* * *, * *, *$ Represent significance at the $1 \%, 5 \%$, and $10 \%$ level, respectively

that SOA of FC firms is more sensitive to optimal cash levels than UC firms. Further, the FC firms tend to avoid the cost of cash shortfall, therefore, prefer to hold larger cash for quick adjustment of cash holdings towards the optimal level. Column 3 and 4 exhibit the cash holdings and SOA across firm size criteria. The SOA of FC firms $(0.408)$ is faster than 
UC firms (0.356). Accordingly, small size firms tend to adjust their cash level more quickly towards their optimal cash target due to the limited access to external financing. Moreover, small size firms have fewer financial resources compared to large-size firms, therefore, prefer to maintain optimal cash level by a quicker SOA towards the target to avoid financial distress. Furthermore, small firms suffer agency conflict and the higher level of information asymmetries which induce professional managers for faster SOA towards the target level. Our results demonstrate that it is more expensive for small firms to deviate from their cash holdings target compared to large firms due to the high financial constraints.

Column 5 and 6 shows that the SOA of low growth firms (0.511) is quicker than the SOA of high growth firms (0.449), and similarly, model 7 and 8 indicate that the SOA of lower interest coverage firms (0.495) is marginally greater than SOA of high-interest coverage firms (0.467). Therefore, FC firms swiftly manage their cash target compared to UC firms indicating that it is expensive for FC firms to operate below the optimal levels of cash holdings. Overall, these findings substantiate a direct association between financial constraints, firms' cash holdings and its SOA. Accordingly, maintenance of an optimal level of cash balance is deemed to be a significant concern for the managers of FC firms as it saves them from transactional cost and help to minimize the default risk. Based on these findings we accept the hypothesis $\mathrm{H}_{3}$.

\subsection{Do a regime shift in the firms demand function of cash holding during the post-crisis period}

The global financial crisis affects the firms' cash management strategies and raised the importance of firms' liquid assets management. Santos (2011) reveals that the bank credit reduces during the financial crisis which increases the firms cost of external financing. Therefore, in the case of the inefficient capital market firms prefer to hold more cash for the transactional and precautionary motive. To examine the influence of exogenous shock on cash holdings, we incorporate the impact of the global financial crisis (2008-2009). Accordingly, we investigate the firms cash holdings management across pre-crisis (2000-2007) and post-crisis (2008-2016) to determine whether there is a regime shift in firms demands function of cash holding in response to the financial crisis.

We categories observations across each country to investigate the impact of financial crisis on each sample. Column 1 of Table 9 presents the estimation of pooled OLS model while in column 2 the log-linear model is estimated for the full sample. A dummy variable e.g. 'post-crisis dummy' is included in model 1 and 2 to investigate whether a regime change in the firms' cash demand function and allow intercept shifts during the post-crisis period. We expect that the coefficient on post-crisis dummy would positively significant if there is an increase in cash holdings 'during the post-crisis period for exogenous factors which are not related to the firms' characteristics. The results show that the coefficients on post-crisis dummy variable in model 1 and 2 are significantly positive e.g. (0.553) and (0.237), respectively indicating a sharp upward shift in firms demands function of cash holdings. These results show that the global financial crisis systematically changed the firms' cash holdings target which describes that a regime changed in the Scandinavian firms' demand function during the post-crisis period. Moreover, these trends show an increased cash holding during the post-crisis period which more likely to induces professional managers towards a quicker SOA due to the exogenous shock. 


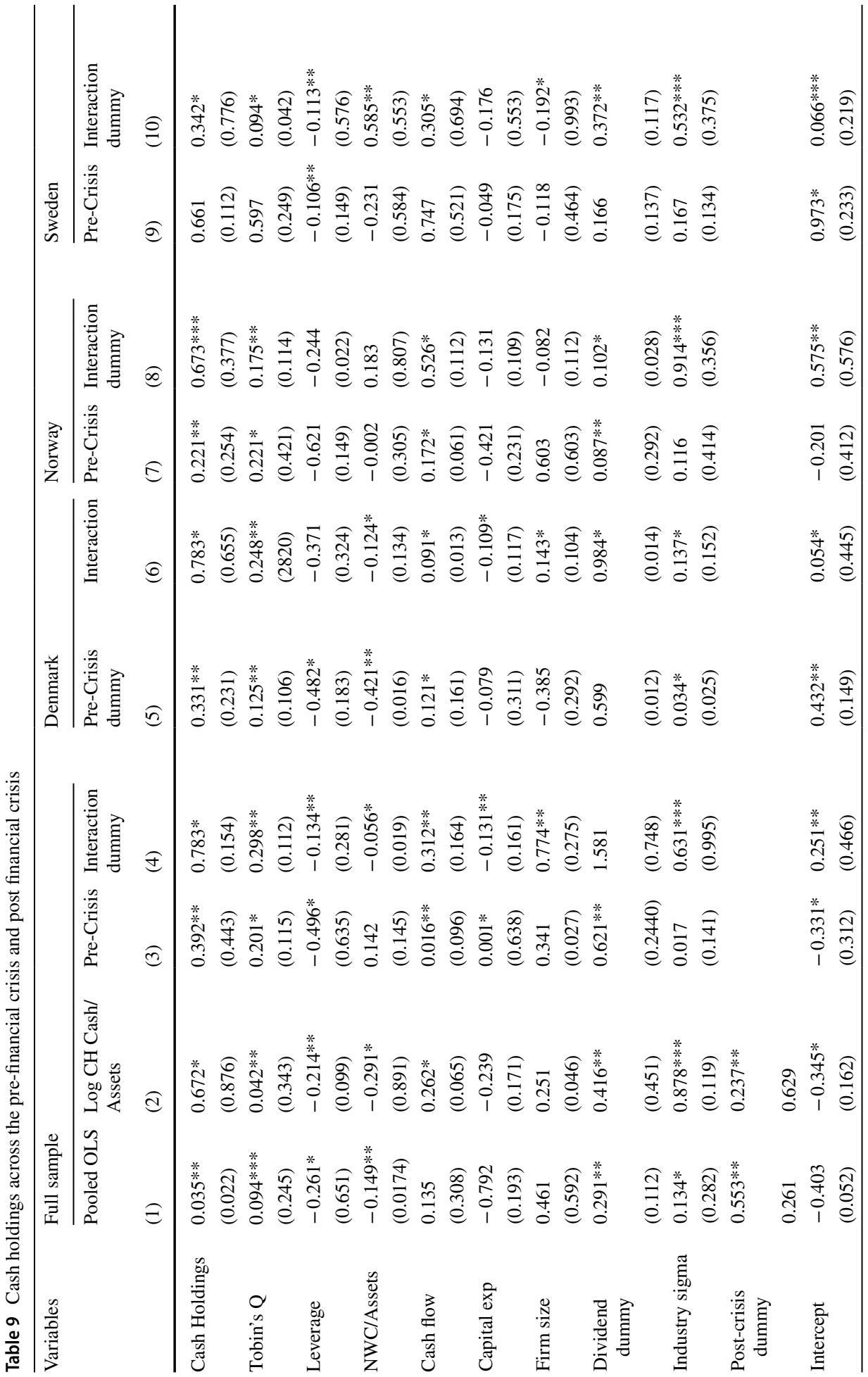




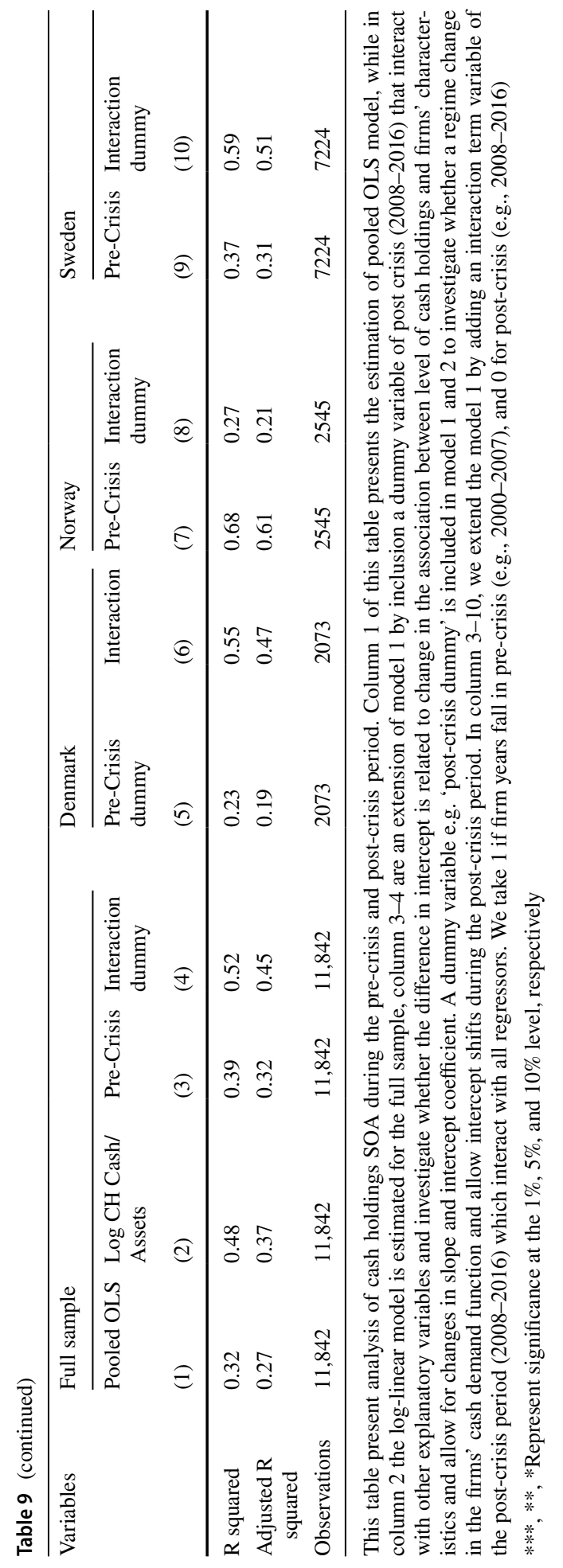


In column 3-10, we extend the model 1 by adding an interaction term variable of the post-crisis period (2008-2016) which interact with all regressors. We take 1 if firm years fall in pre-crisis (e.g., 2000-2007) and 0 for post-crisis (e.g., 2008-2016). This interaction variable determines whether the difference in intercept is associated with the change in the relationship between cash holdings and firms' characteristics and allow for a shift in slope and intercept during the post-crisis. Column 3 shows that during post-crisis there is a significant increase in industry sigma (0.631) compared to the pre-crisis period. Moreover, the coefficient on industry sigma is also increased for the individual samples in column 6,8 and 10. This result reflects that firms prefer to hold more cash to mitigate cash flow risk during the post-crisis period. Further, results show that the intercepts are significantly increased across all samples which change the slope coefficients in the post-crisis period. These results demonstrate that a significant part of increased cash holdings during postcrisis is not explained by the relationship between firms' internal characteristics and cash holdings which deems to be an undefined shift in the firms' demand function due to exogenous shock which is not related to firm characteristics.

\subsection{Do firms SOA accelerate during the post-crisis?}

In the line of the previous analysis, we examine whether Scandinavian firms' SOA accelerates during the post-crisis due to the increase in cash holdings. Therefore, distinct from Table 9, instead of using dummy a variable and interaction variable for the post-crisis period, we split the firm-years into the pre-crisis period (2000-2007) and the post-crisis period (2008-2016). We apply the two-steps system GMM estimator which provide more efficient and consistent estimation after controlling dynamic endogeneity and present the findings in Table 10. The results demonstrate that $p$ value of Arellano and Bond AR (2) and the $p$ value of Hansen test are sufficiently high across all models, therefore, the null hypothesis of instruments validity and instruments exogeneity cannot be rejected. Moreover, Wald f-statistic reflecting the difference in the coefficient across different groups. The results show that the SOA of Scandinavian firms (full sample) in the pre-crisis increase from (0.389) to (0.491) during the postcrisis period indicating that Scandinavian firms exhibit quicker SOA during the post-crisis period. These findings strongly support the hypothesis $H_{4}$. Column 3 and 4 shows that SOA of Danish firms in the pre-crisis increase from (0.411) to (0.512) during the post-crisis period indicating a quicker SOA of Danish firms during the post-crisis period. In the case of Norwegian firms, the SOA is marginally increased from (0.446) to (0.451) during the post-crisis period reflecting that Norwegian firms are not sensitive towards the financial crisis. This evidence is corroborating with cash holdings trends of Norwegian firms report in Table 1, indicating that cash holdings of Norwegian firms remain consistent during the post-crisis period. Finally, SOA of Swedish firms is (0.369) in pre-crisis and increased up to (0.401) during the post-crisis period. Taken together, Scandinavian firms except Norway accelerate SOA during the post-crisis period by reason of their sensitivity towards exogenous shocks.

\section{Concluding remarks}

We investigate the firms' specific attributes that determine the difference in speed of adjustment (SOA) towards the cash holdings target in the Scandinavian countries: Denmark, Norway and Sweden. Our analysis differs from previous empirical research on various 


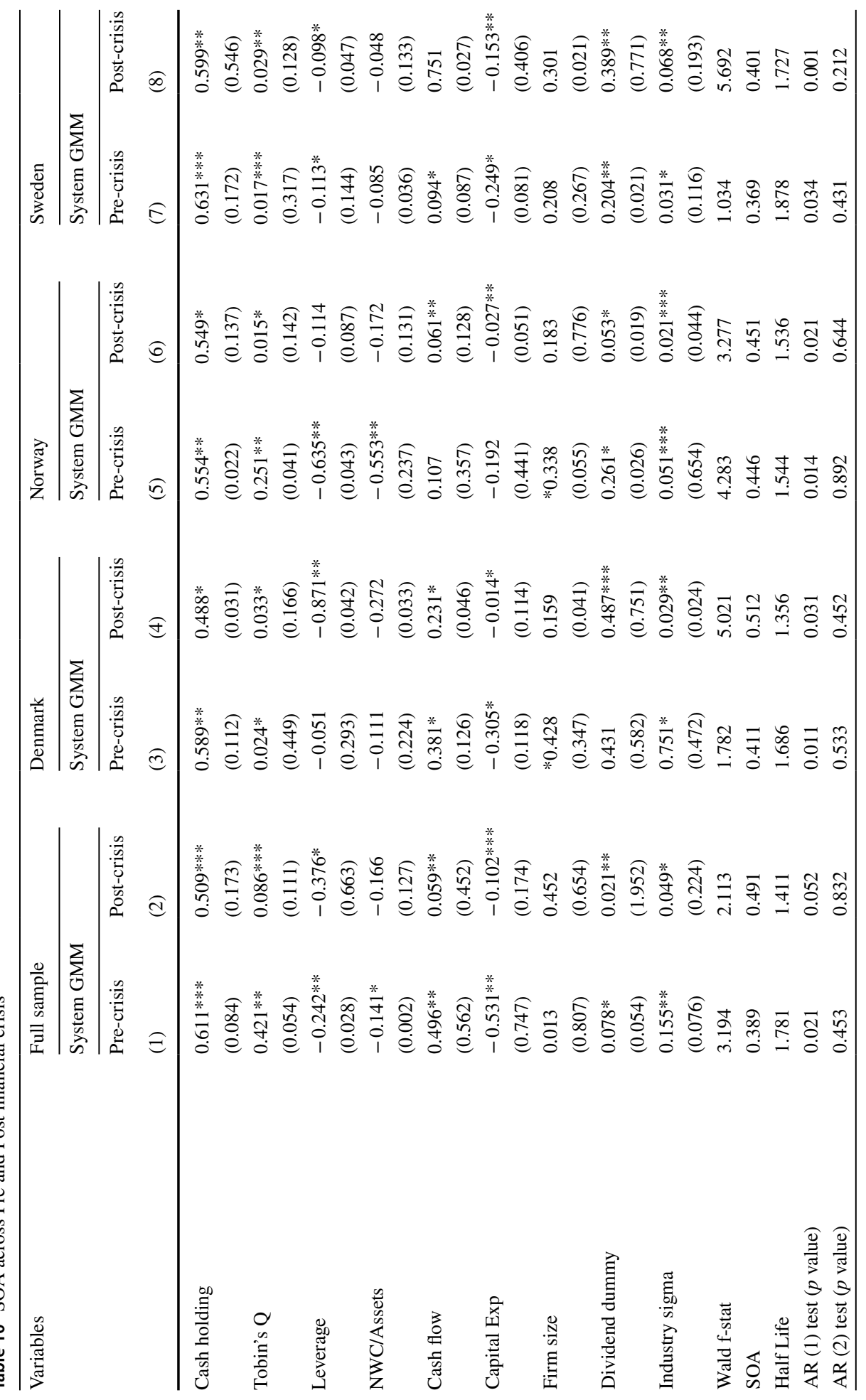




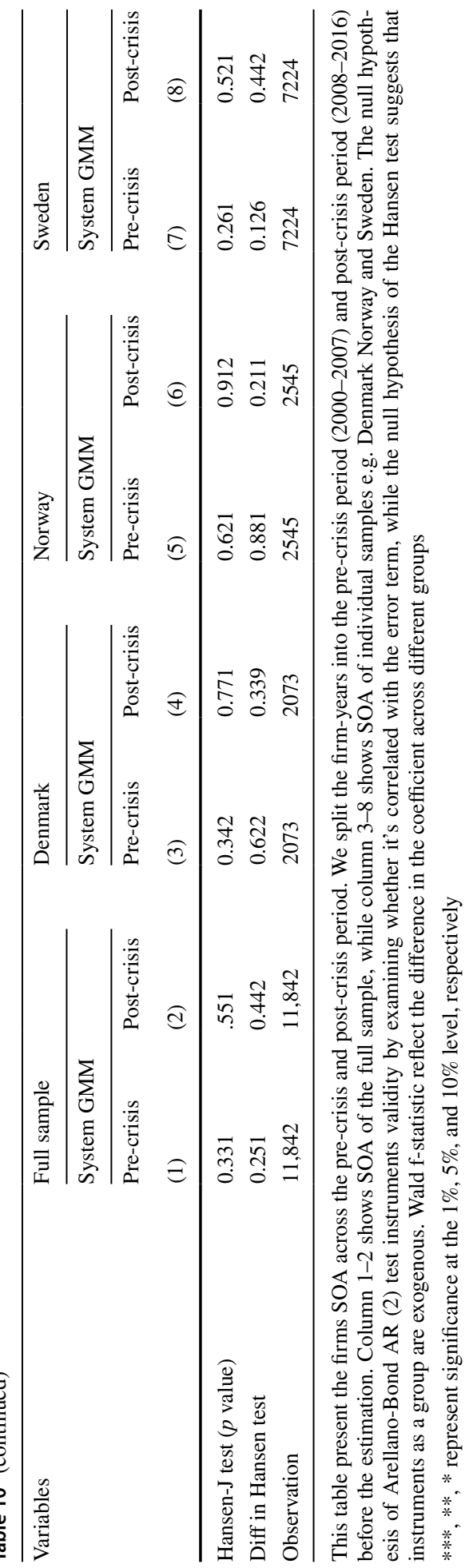


counts and contributes to the growing literature of ownership structure in several notable ways. The present study is the first to examine cash holdings SOA in the Scandinavian firms' context. Our results demonstrate that Scandinavian firms are not persistent across high cash firms and cash deficit firms and adjust their cash level in the subsequent year. In addition, we report that firms exhibit mean reversion towards their cash holdings level and tend to actively correct their deviations for optimal levels. The Scandinavian firms on average covers less than half the gap between their actual cash level and the target level of cash holdings and revert towards optimal cash level in less than 2 years.

Our findings add substantial evidence of country-specific attributes that significantly influence the firms' cash holdings. For example, the SOA of Norwegian firms is significantly larger than the Danish and Swedish firms due to the stable cash holdings level across the sample period. Also, we report that the adjustment costs and off-target costs of Norwegian firms are marginally close to each other which lead to quicker deviation towards the target. Additionally, the half-life period of Norwegian firms is significantly lower than other samples, reflecting their quicker SOA and stable cash holdings levels across the sample period.

Our results show that the firms' SOA is heterogeneous across sample firms, therefore, the SOA of the firms with higher leverage finance and greater investment level is faster than lower leverage finance and smaller investment firms as the professional managers need to manage cash for debts repayments and potential investment opportunities. Further, the firms' active cash holdings management associated with the higher SOA and lower adjustment cost. The Scandinavian firms' SOA determined mainly by adjustment cost in addition to firms' capacity and initiative to rebalance the cash level towards the targets. We argue that an exogenous shock, financial constraints, agency issues and information asymmetry trigger the intensity of adjustment cost.

Our analysis substantiates that financially constrained (FC) firms endeavour to cover their transaction cost for unconditional liquidity thus behave more sensitive for optimal cash level. We report that FC firms quickly deviate their cash towards the target compared to unconstrained (UC) firms which in turn increase the SOA of FC firms than UC firms. We thus conclude that cash flow volatility and financial constraints determine the level of cash holdings of FC firms. Moreover, we argue that the professional managers of FC firms are more concerned about cash shortfall and prefer to maintain an optimal level of cash holdings compared to UC firms as it's costlier for FC firms to maintain cash holdings below the optimal level.

Our results show that Scandinavian firms prefer to hold more cash in the post-crisis period for the transactional and precautionary motive which induces professional managers towards a quicker SOA. We further report a sharp upward shift in firms' demands function of cash holdings which describe that a regime changed in the Scandinavian firms' cash holdings during the post-crisis period which leads to faster SOA. Finally, we empirically test the significance of trade-off and financial hierarchy theories and report that Scandinavian firms deviate their cash holdings towards the optimal level thus better described by the trade-off theory. We provide valuable insights for key stakeholders i.e., shareholders directors, and professional managers by presenting a wider dimension of cash holdings SOA across different economic periods and financial constraint criteria. Our findings add value to the growing literature by providing an obstinate platform for future studies to analyse the distinctive aspects of SOA across developed and emerging market. 
Funding Funding was provided by Coventry University.

\section{References}

Acharya VV, Almeida H, Campello M (2007) Is cash negative debt? A hedging perspective on corporate financial policies. J Financ Intermed 16:515-554

Akbar S, Poletti H, El-Faitouri R, Shah ZAS (2016) More on the relationship between corporate governance and firm performance in the UK. Res Int Bus Finance 38:417-429

Almeida H, Campello M, Weisbach M (2004) The cash flow sensitivity of cash. J Finance 59:1777-1804

Arslan-Ayaydin O, Florackis C, Ozkan A (2014) Financial flexibility, corporate investment and performance: evidence from financial crisis. Rev Quant Finance Account 42:211-250

Bates TW, Kahle KM, Stulz R (2009) Why do U.S. firms hold so much more cash than they used to? J Finance 64:1985-2021

Bates WT, Chang CH, Chi D (2018) Why has the value of cash increased over time. J Financ Quant Anal 53:749-787

Baum CF, Caglayan M, Ozkan N, Talavera O (2006) The impact of macroeconomic uncertainty on nonfinancial firms demand for liquidity. Rev Financ Econ 15:289-304

Belghitar Y, Khan J (2013) Governance mechanisms, investment opportunity set and SMEs cash holdings. Small Bus Econ 40:59-72

Bigelli M, Sanchez-Vidal J (2012) Cash holdings in private firms. J Bank Finance 36:26-35

Bond SR (2002) Dynamic panel data models: a guide to micro data methods and practice. Port Econ J $1: 141-162$

Brick EI, Liao CR (2017) The joint determinants of cash holdings and debt maturity: the case for financial constraints. Rev Quant Finance Account 48:597-641

Chan CK, Bao D, Zhang W (2012) Asymmetric cash flow sensitivity of cash holdings. J Corp Finance 18:690-700

Chang Y, Benson K, Faff R (2017) Are excess cash holdings more valuable to firms in times of crisis? Financial constraints and governance matters. Pac Basin Finance J 45:157-173

Chen Q, Chen X, Schipper K, Xu Y, Xue J (2012) The sensitivity of corporate cash holdings to corporate governance. Rev Financ Stud 25:3610-3644

Denis D, Sibilkov V (2010) Financial constraints, investment, and the value of cash holdings. Rev Financ Stud 23:247-269

Dittmar A, Duchin R (2010) The dynamics of cash. Working paper. The University of Michigan

Dittmar A, Mahrt-Smith J (2007) Corporate governance and the value of cash holdings. J Financ Econ 83:599-634

Dittmar A, Mahrt-Smith J, Servaes H (2003) International corporate governance and corporate cash holdings. J Financ Quant Anal 38:111-134

Foley CF, Hartzell CJ, Titman S, Twite G (2007) Why do firms hold so much cash? A tax-based explanation. J Financial Econ 86:579-607

Faulkender M, Wang R (2006) Corporate financial policy and the value of cash. J Finance 61:1957-1990

Ferreira MA, Vilela AS (2004) Why do firms hold cash? Evidence from EMU countries. Eur Financ Manag 10:295-319

Fischer E, Heinkel R, Zechner J (1989) Dynamic capital structure choice: theory and tests. J Finance 44:19-40

Frank ZM, Goyal KV (2003) Testing the pecking order theory of capital structure. J Financ Econ 67:217-248

Gao H, Harford J, Li K (2013) Determinants of corporate cash policy: insights from private firms. J Financ Econ 109:623-639

Garcia-Teruel PJ, Martinez-Solano P (2008) On the determinants of SME cash holdings: evidence from Spain. J Bus Finance Account 35:127-149

Guariglia A, Yang J (2018) Adjustment behaviour of corporate cash holdings: the China experience. Eur J Finance 24:1428-1452

Han S, Qiu J (2007) Corporate precautionary cash holdings. J Corp Finance 13:43-57

Harford J (1999) Corporate cash reserves and acquisitions. J Finance 54:1969-1997

Harford J, Mansi S, Maxwell W (2008) Corporate governance and firm cash holdings in the US. J Financ Econ 87:535-555 
Jiang Z, Lie E (2016) Cash holding adjustments and managerial entrenchment. J Corp Finance 36:190-205

Jun S, Jen F (2003) Trade-off model of debt maturity structure. Rev Quant Finance Account 20:5-34

Kalcheva I, Lins K (2007) International evidence on cash holdings and expected managerial agency problems. Rev Financial Study 20:1087-1112

Kim C, Mauer DC, Sherman AE (1998) The determinants of corporate liquidity: theory and evidence. J Finance Quant Anal 33:335-359

Kwak W, Shi Y, Kou G (2012) Bankruptcy prediction for Korean firms after the 1997 financial crisis: using a multiple criteria linear programming data mining approach. Rev Quant Finance Account 38(4):441-453

La Porta F, De Silanes LF, Shleifer A (1998) Corporate ownership around the world. Harvard Institute of Economic Research Paper No. 1840

Lee KW, Lee CF (2009) Cash holdings, corporate governance structure and firm valuation. Rev Pac Basin Financ Mark Policies 12(3):475-508

Lee C, Park H (2016) Financial constraints, board governance standards, and corporate cash holdings. Rev Financ Econ 28:21-34

Lian Y, Xu Y, Zhou K (2012) How and why do firms adjust their cash holdings toward targets? Evidence from China. Front Bus Res China 6(4):527-560

Martinez-Sola C, Garcia-Terue PJ, Martinez-Solano P (2018) Cash holdings in SMEs: speed of adjustment, growth and financing. Small Bus Econ 51:823-842

Megginson WL, Ullah B, Wei Z (2014) State ownership, soft-budget constraints, and cash holdings: evidence from Chinas privatized firms. J Bank Finance 48:276-291

Myers SC, Majluf N (1984) Corporate financing and investment decisions when firms have information that Investors do not have. J Financ Econ 13:187-221

Nguyen C (2018) The asymmetry in firms' mechanisms of cash holdings adjustments: evidence from the G-5 economies. Rev Quant Finance Account 52:1-35

Nikolov B, Whited MT (2014) Agency conflicts and cash: estimates from a dynamic model. J Finance 69:1883-1921

Opler T, Pinkowitz L, Stulz R, Williamson R (1999) The determinants and implications of corporate cash holdings. J Financ Econ 52:3-46

Orlova S, Rao R (2018) Cash holdings speed of adjustment. Int Rev Econ Finance 54:1-14

Orlova S, Rao R, Kang T (2017) National culture and the valuation of cash holdings. J Busi Finance Acc 44:236-270

Ozkan A, Ozkan N (2004) Corporate cash holdings. an empirical investigation of UK companies. J Bank Finance 28:2103-2134

Oztekin O, Flannery MJ (2012) Institutional determinants of capital structure adjustment speeds. J Financ Econ 103:88-112

Pinkowitz L, Stulz R, Williamson R (2006) Does the contribution of corporate cash holdings and dividends to firm value depend on governance? A cross-country analysis. J Finance 61:2725-2751

Ramadan EF (2014) Board of directors and Tobin's Q: evidence from U.K firms. J Finance Account 2:82-99

Riddick L, Whited T (2009) The corporate propensity to save. J Finance 64:1729-1766

Santos ACJ (2011) Bank corporate loan pricing following the subprime crisis. Rev Financ Stud 24:1916-1943

Song KR, Lee Y (2012) Long-term effects of a financial crisis: evidence from cash holdings of east Asian firms. J Financial Quant Ana 47(3):617-641

Venkiteshwaran V (2011) Partial adjustment toward optimal cash holding levels. Rev Financ Econ 20:113-121

Wintoki MB, Linck JS, Netter JM (2012) Endogeneity and the dynamics of internal corporate governance. J Financ Econ 105:581-606

Publisher's Note Springer Nature remains neutral with regard to jurisdictional claims in published maps and institutional affiliations. 